\title{
PROCEDIMENTOS DE PRÓTESE BUCOMAXILOFACIAL APÓS TRATAMENTO CIRÚRGICO DE NEOPLASIA: RELATO DE CASO
}

\section{ARTIGO ORIGINAL}

SANTOS, Isadora Alice Fachini dos ${ }^{1}$

SILVA, Franklin Barbosa da ${ }^{2}$

AGUIAR, Felipe Muniz ${ }^{3}$

PINHEIRO, Tiago Novaes ${ }^{4}$

BRAGA, Francisco Pantoja ${ }^{5}$

SANTOS, Isadora Alice Fachini dos. Et al. Procedimentos de prótese bucomaxilofacial após tratamento cirúrgico de neoplasia: Relato de caso. Revista Científica Multidisciplinar Núcleo do Conhecimento. Ano 05, Ed. 07, Vol. 01, pp. 87-111. Julho de 2020. ISSN: 2448-0959, Link de acesso: https://www.nucleodoconhecimento.com.br/odontologia/protesebucomaxilofacial

${ }^{1}$ Graduada em Odontologia, Universidade Nilton Lins.

2 Doutor em Saúde Pública. Especialista em Prótese Dentária. Professor de Prótese Total e Oclusão, Curso de Odontologia, Universidade Nilton Lins.

${ }^{3}$ Especialista em Cirurgia e Traumatologia Buco-maxilo-facial. Professor de Estágio em Cirurgia Bucal I, Curso de Odontologia, Universidade Nilton Lins.

4 Doutor em Odontologia - Patologia Bucal. Especialista em Patologia Bucal. Professor de Patologia Bucal, Curso de Odontologia, Universidade do Estado do Amazonas.

${ }^{5}$ Mestre em Clínica Odontológica. Especialista em Prótese Dentária. Professor de Prótese Total, Prótese Fixa, Prótese Removível e Oclusão, Curso de Odontologia, Universidade do Estado do Amazonas. 


\section{RESUMO}

Diante das neoformações malignas de cabeça e pescoço, o carcinoma mucoepidermoide apresenta-se como uma das manifestações de grande ocorrência, sendo a região do palato a mais envolvida. Podendo o tratamento resultar em mutilações na cavidade oral, ocasionando comunicação bucosinusal, a qual poderá ser restaurada por intermédio de próteses obturadoras. O objetivo do presente trabalho é relatar um caso clínico de confecção de prótese obturadora palatina oca em paciente portador de carcinoma mucoepidermoide após maxilectomia parcial, e, a técnica de moldagem facial prévia a tratamento cirúrgico de recidiva. Paciente buscou atendimento odontológico, mencionando apresentar sua prótese total obturadora mal adaptada devido o tempo de uso. Seu plano de tratamento, consistiu na confecção da prótese obturadora pela técnica da clonagem e prótese parcial removível convencional. Após alguns meses, detectou-se clinicamente a recidiva da lesão, onde foi realizado novo procedimento cirúrgico, o qual não obteve sucesso. Então optou-se por outra abordagem, desenvolvendo a moldagem facial, pois uma cirurgia mais invasiva seria necessária, podendo trazer consequências na face. A paciente encontrava-se em tratamento radioterápico, sendo a nova intervenção médica escolhida. A prótese obturadora é uma alternativa eficaz na reabilitação de pacientes submetidos a ressecções cirúrgicas, as quais resultaram em mutilações. Sendo assim, a escolha pela técnica da clonagem com algumas modificações, nesse caso além do custo-benefício, as etapas clínicas e laboratoriais foram reduzidas e como consequência a substituição da prótese foi mais rápida eficaz. Além disso, é de grande relevância o papel dessa reabilitação na reintegração do indivíduo no meio biopsicossocial, o restabelecimento da função, estética e conforto.

Descritores: Carcinoma mucoepidermoide, obturadores palatinos, prótese maxilofacial, prótese parcial removível.

\section{INTRODUÇÃO}

As neoformações malignas de cabeça e pescoço constituem cerca de $5 \%$ de todos os tumores existentes, é denotado em sua grande parte por carcinoma espinocelular 
também intitulado epidermoide ou carcinoma de células escamosas, estando entre as doenças cancerígenas mais recorrentes no Brasil (RETTIG e D'SOUZA, 2015). Estudos evidenciam maior predominância em países subdesenvolvidos, sendo os homens mais acometidos do que as mulheres em uma proporção de 2:1 entre a quarta e sétima décadas de vida. As principais ameaças para o progresso desse tipo de câncer bucal é o consumo de tabaco e álcool combinados, baixo nível socioeconômico e educacional (REZENDE, 1997; SOUSA et al., 2016).

A distinção do tratamento nas doenças malignas de cabeça e pescoço pode ser executada através de cirurgia, radioterapia, quimioterapia ou terapia combinada. A terapêutica em fase preliminar por meio de cirurgia ou radioterapia, irá decorrer da preferência do paciente, conforto, custo, localização e o domínio da doença. A radioterapia mesmo revelando resultados satisfatórios, poderá deixar sequelas na pele, mucosa, glândulas salivares e dente (ARTOPOULOU et al., 2017). E a quimioterapia em muitos episódios é aplicada como alternativa paliativa ou na terapia combinada. Desta forma, a cirurgia ainda é o tratamento prevalente, cujo propósito é a remoção cirúrgica integral com margens livres diminuindo a morbidade das doenças (CAMPANA e GOIATO, 2013; REZENDE, 1997).

Quando há ocorrências de tumor maxilar, para controle da sua dissipação será executada a excisão maxilar e palatina, sendo a maxilectomia total ou parcial, afligindo diretamente a funcionalidade da maxila (GASTALDI et al., 2017), a qual desempenha seu papel na fonação, mastigação e deglutição(CAMPANA e GOIATO, 2013). No que Ihe concerne, a realização desse tipo de tratamento irá promover deformidades funcionais na cavidade oral ocasionando comunicação buco-sinusal, as quais podem ser restauradas por intermédio de próteses obturadoras, abstendo-se a fala anasalada e vazamento de líquidos no interior da cavidade nasal (BADADARE et al., 2014).

As próteses obturadoras são classificadas de acordo com a área de atuação e podem ser divididas em: prótese reparadora interna (tutora do periósteo e restauradora do esqueleto facial); externa imediata (profilática da retração cicatricial, tutora do periósteo) e tardia (corretora da cicatrização e restauradora) (REZENDE, 1997). A confecção de prótese obturadora palatina é primordial na reestruturação das 
imperfeições decorrentes da maxilectomia total ou parcial. Para cada deformação maxilar possui uma possibilidade de elaboração de um obturador palatino, caso seja de grande espessura, a estabilidade da prótese poderá ser prejudicada. Um fator bastante significativo é o peso da prótese sendo recomendo a produção do obturador oco, o qual viabiliza o bem-estar do paciente (LIKHTEROV et al., 2017). Além de defeitos na cavidade oral, as ressecções cirúrgicas podem acometer deformações na face, sendo fundamental a execução da moldagem facial para posterior planejamento, no qual o modelo facial é a reprodução da face do paciente para subsequente reabilitação protética (AQUINO et al., 2012).

O objetivo do presente trabalho é relatar um caso clínico de confecção de prótese obturadora palatina oca em paciente portador de carcinoma mucoepidermoide após maxilectomia parcial, e, a técnica de moldagem facial prévia à procedimento cirúrgico invasivo.

\section{RELATO DE CASO}

Paciente 49 anos, gênero feminino, compareceu a clínica de prótese da Universidade Nilton Lins, mencionando insatisfação com sua prótese total obturadora, pois a mesma estava com o "dente da frente quebrado" e a prótese estava "caindo", enfatizando o desejo de manter o formato da mesma. $\mathrm{Na}$ anamnese relatou que anteriormente em 2012 teve diagnóstico de carcinoma mucoepidermoide de grau intermediário no palato (anexo 1) e em 2013 depois de realizar a remoção cirúrgica e executar novos exames, os quais não indicaram presença de malignidade (anexo 2), foi atestada como curada, além de ser hipertensa e fazer uso dos medicamentos losartana potássica $50 \mathrm{mg}$ duas vezes ao dia e levanlodipino besilato $2,5 \mathrm{mg}$ uma vez ao dia. No exame clínico extrabucal não foram observadas alterações. No exame clínico intrabucal constatouse ausência dos dentes do arco superior, comunicação bucosinusal e rebordo parcial de maxila e na região inferior presença somente dos dentes 31, 32, 33, 41, 42, 43, 44 e 45 (figuras 1 e 2 ).

O plano de tratamento consistiu na realização de uma prótese total superior obturadora pela técnica da clonagem e a confecção de uma prótese parcial removível 
(PPR) convencional. A clonagem da prótese total superior obturadora iniciou-se com aplicação de vaselina sólida na bancada e na prótese antiga, o silicone de condensação (Clonage ${ }^{\circledR}$, Nova DFL, Brasil) foi manipulado para modelar a parte interna da prótese, recobrindo uma porção da borda externa, deixando-a expulsiva (figura 3).

Figura 1: Defeito cirúrgico do arco superior.

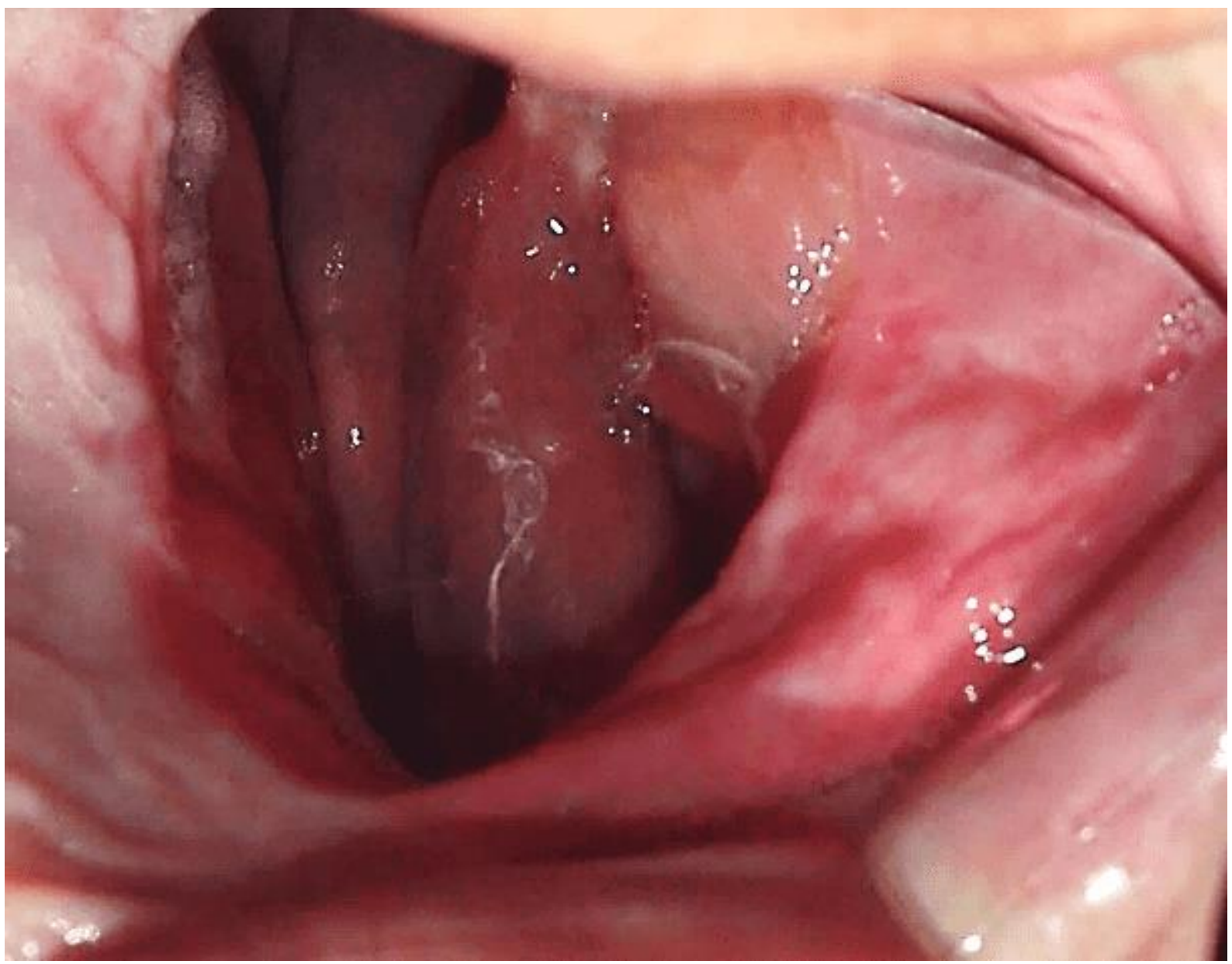

Fonte: Os autores (2020). 
Figura 2: Aspecto inicial da paciente em oclusão.

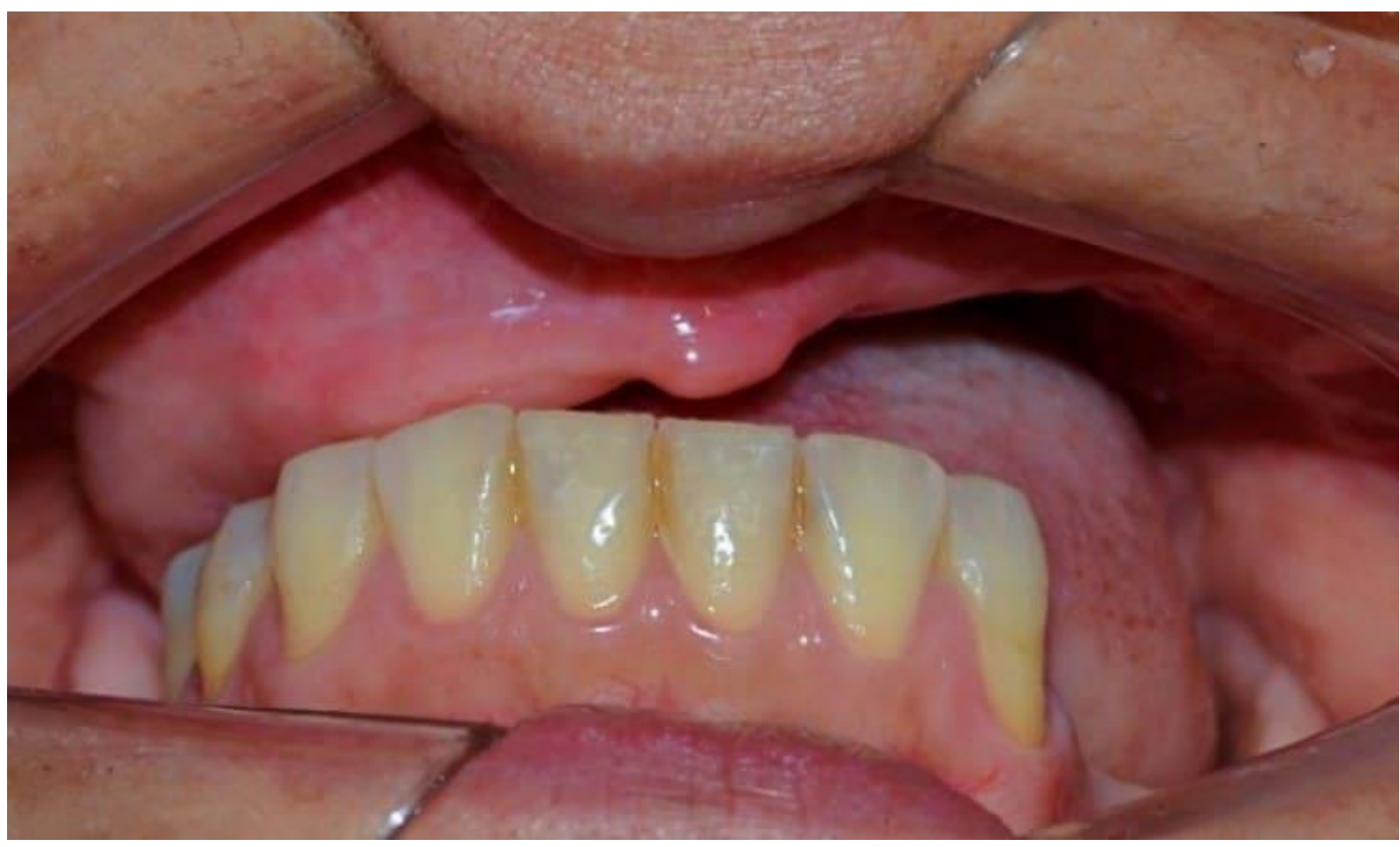

Fonte: Os autores (2020).

Figura 3: Confecção do molde.



Fonte: Os autores (2020).

$\mathrm{RC}: 54698$

Disponível em: https://www.nucleodoconhecimento.com.br/odontologia/protese-bucomaxilofacial 
Em seguida inseriu-se uma fina camada de vaselina sólida na base já modelada e a cobertura e cópia dos dentes foram confeccionadas (figuras 4 e 5). Logo após, foi elaborada uma base da prótese com resina acrílica (Duralay ${ }^{\circledR}$, Reliance, EUA) pela técnica do pincel introduzindo a resina em pequenas proporções, pois esse tipo de material possui menor contração de polimerização (figura 6). Então, foram feitas perfurações na região posterior de cada lado da cobertura, com o intuito de preencher o molde com cera 7 (figura 7). Onde inicialmente efetuou-se o aquecimento da cera até sua fervura e com o auxílio de um gotejador de vidro os incrementos foram adicionados preenchendo por completo o molde (figura 8). E, após o resfriamento da cera, o silicone de cobertura da base foi removido, obtendo assim, a clonagem propriamente referida da prótese antiga (figura 9).

Figura 4: Molde interno.

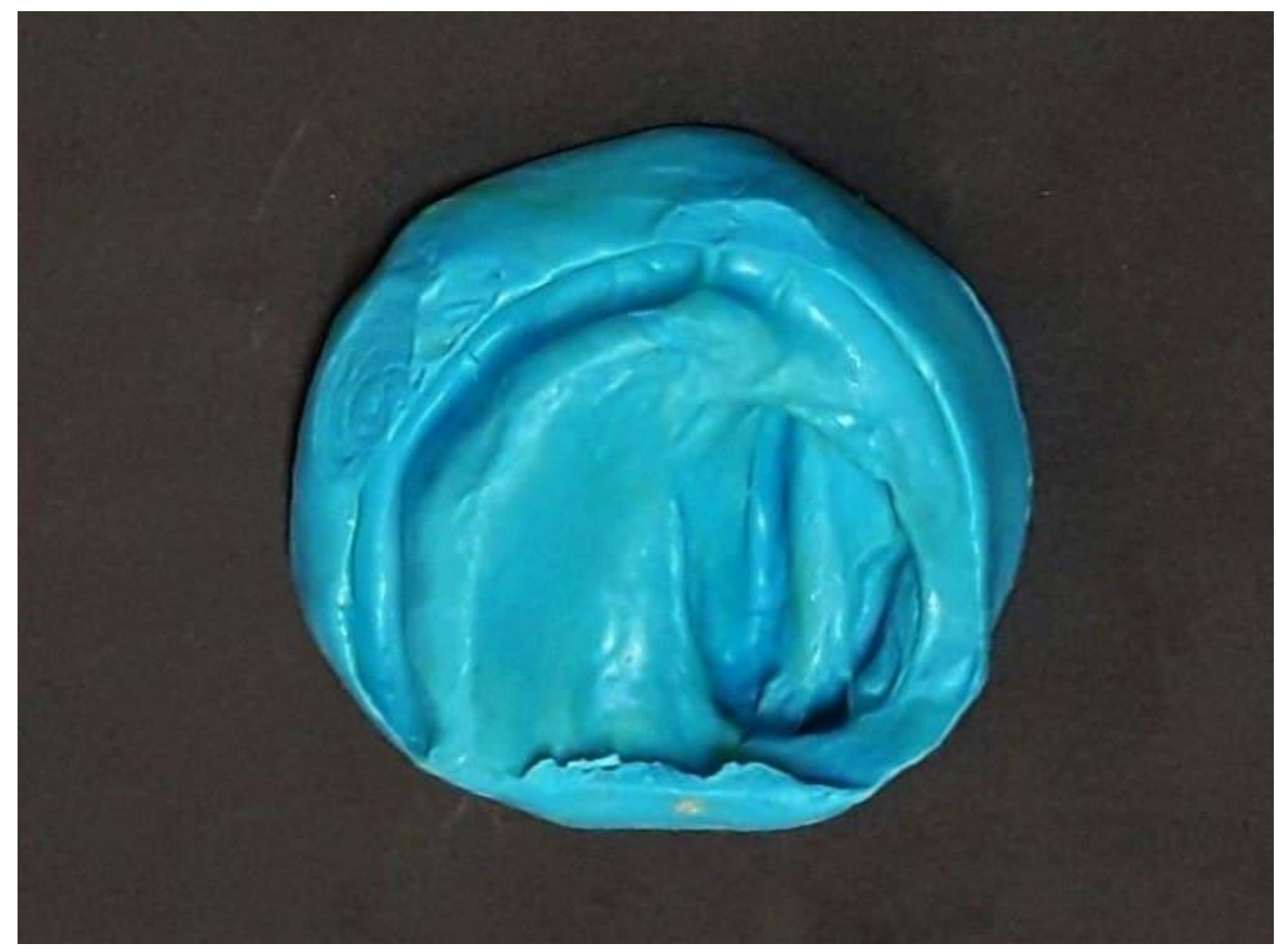

Fonte: Os autores (2020). 
Figura 5: Molde externo.

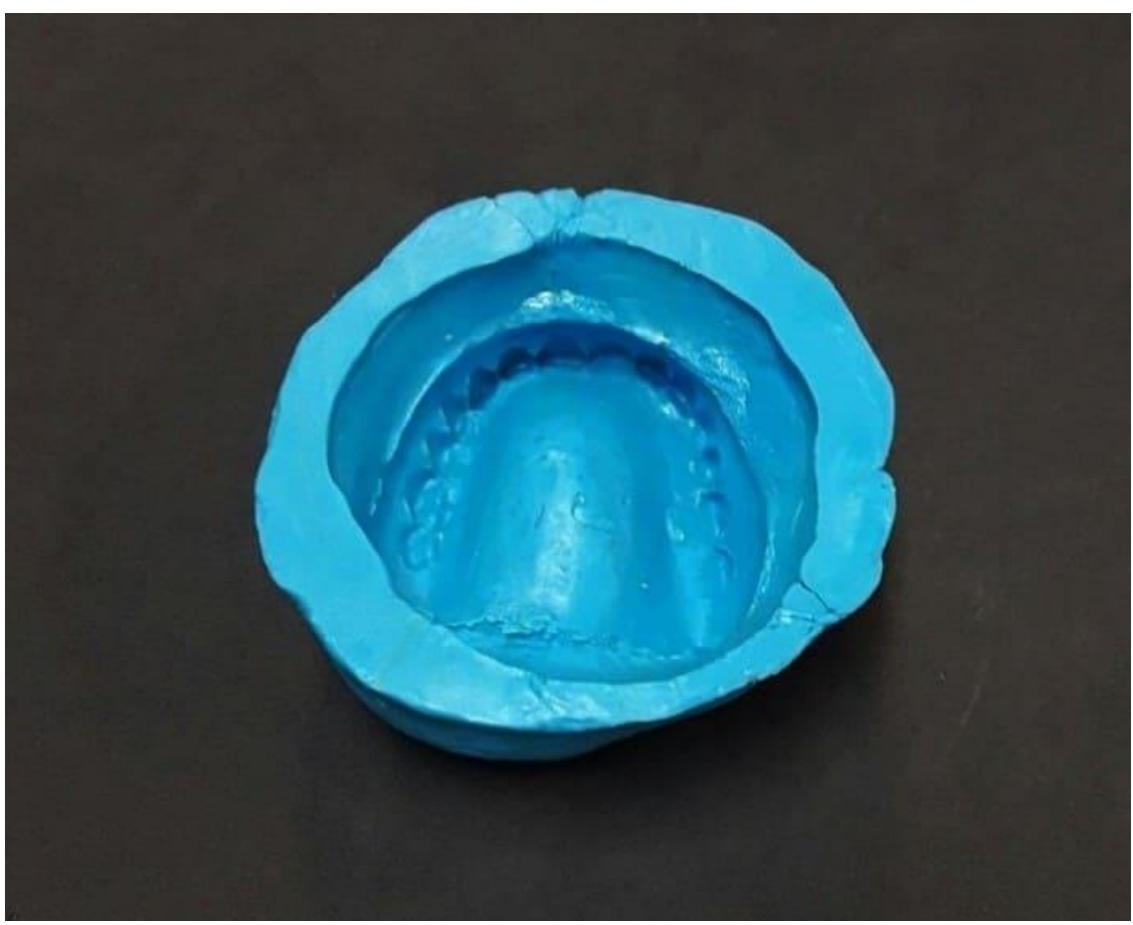

Fonte: Os autores (2020).

Figura 6: Incremento de resina acrílica autopolimerizável.

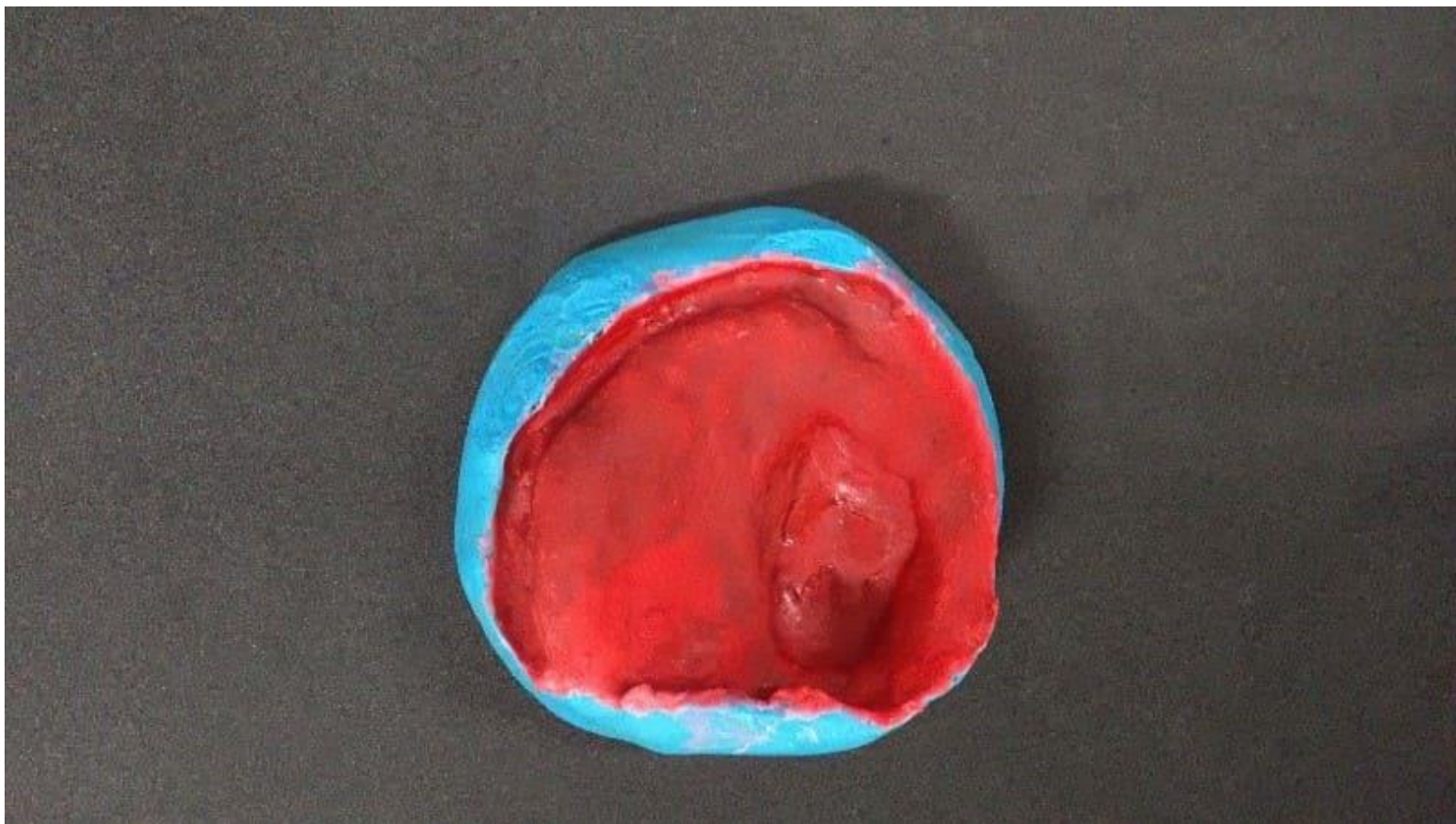

Fonte: Os autores (2020).

$\mathrm{RC}: 54698$

Disponível em: https://www.nucleodoconhecimento.com.br/odontologia/protese-bucomaxilofacial 
Figura 7: Perfurações na região posterior.

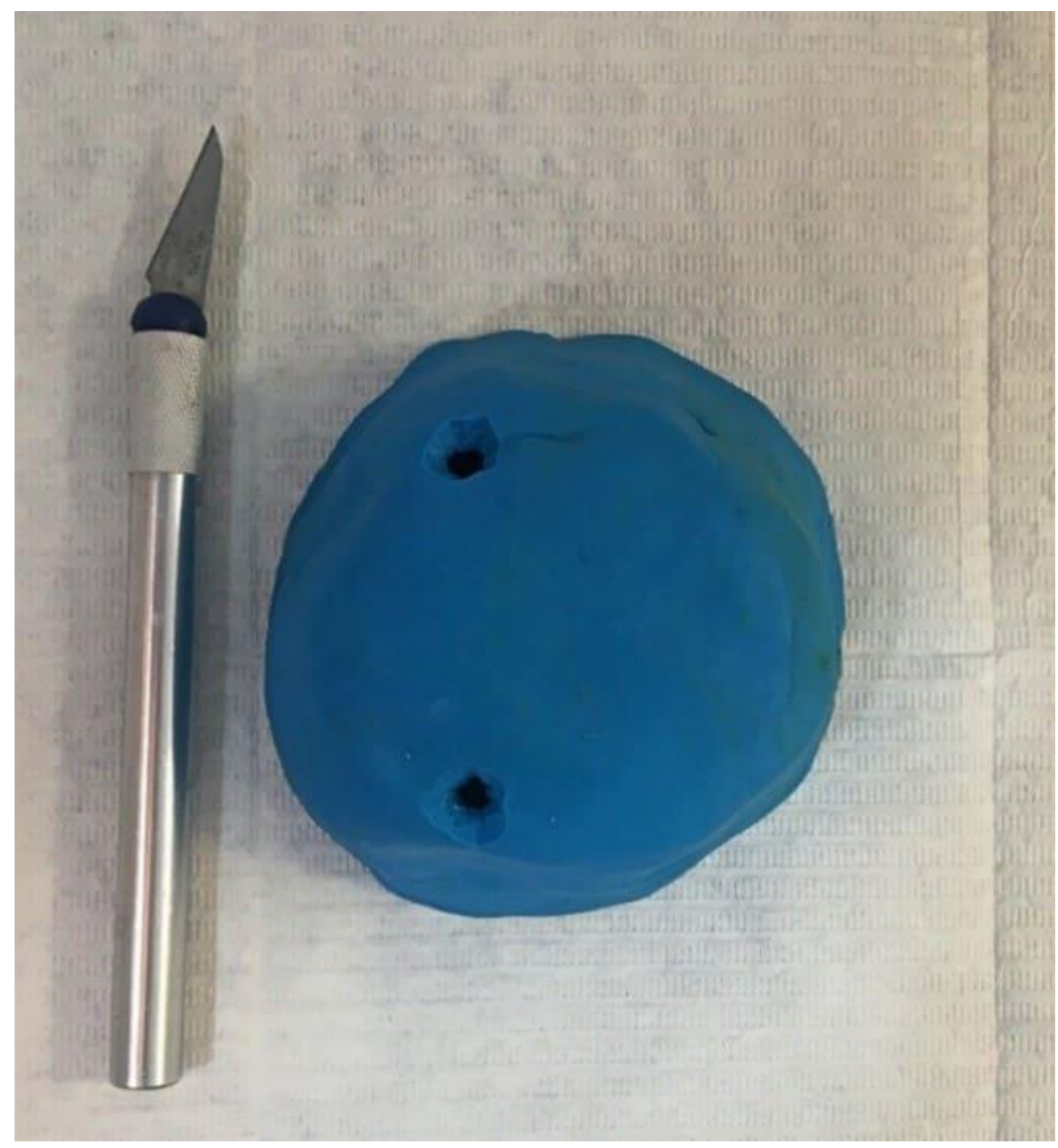

Fonte: Os autores (2020). 
Figura 8: Incrementos de cera 7 adicionados.

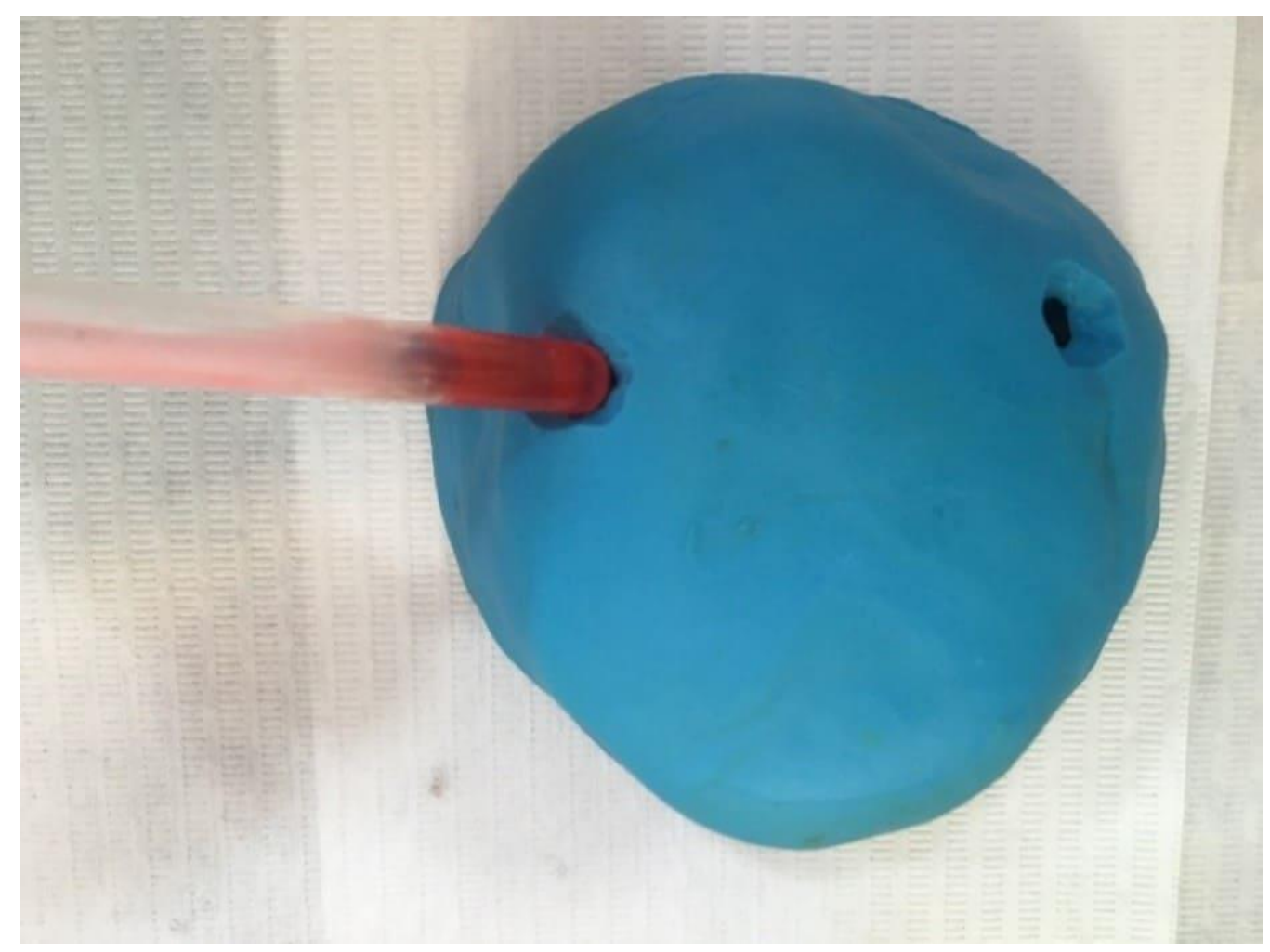

Fonte: Os autores (2020).

Figura 9: Clone da prótese total obturadora.

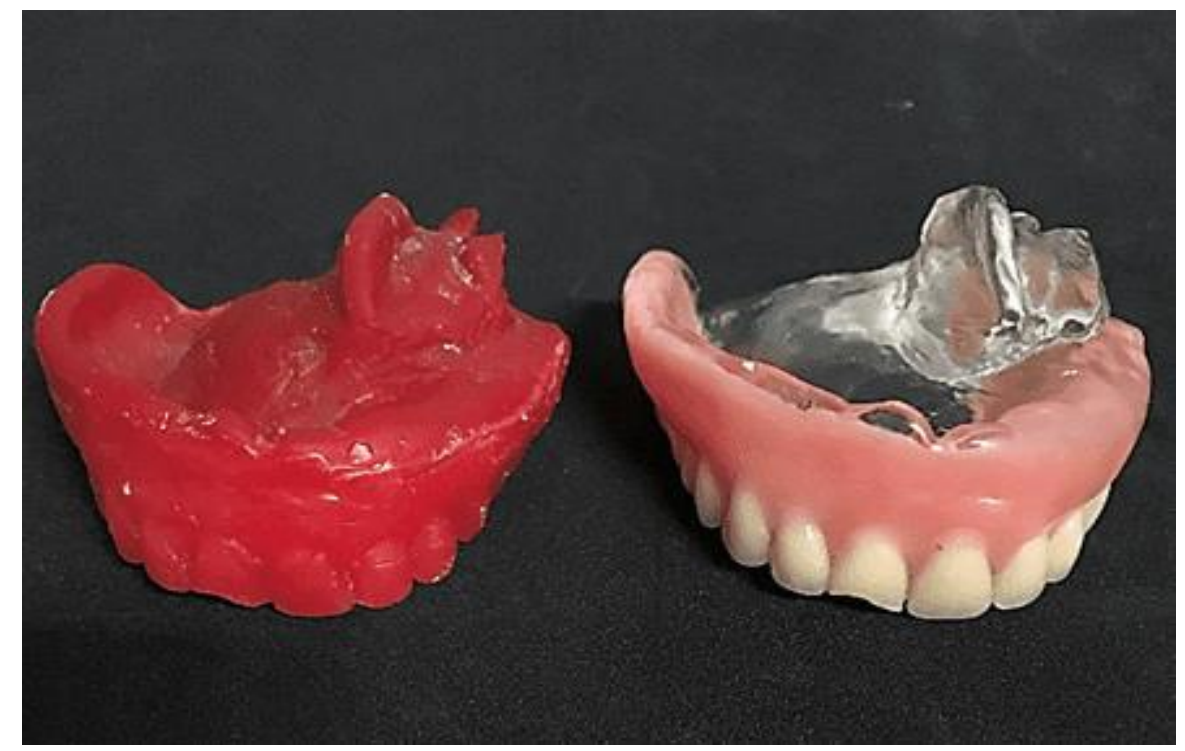

Fonte: Os autores (2020).

RC: 54698

Disponível em: https://www.nucleodoconhecimento.com.br/odontologia/protese-bucomaxilofacial 
Levou-se o clone em boca para conferir a adaptação, não havendo necessidade de ajustes. Foi realizada então a montagem no articulador semi-ajustável (ASA) (Bio-Art 4000-S, Brasil), para isso aqueceu-se a godiva em bastão, a qual foi inserida nas perfurações do garfo, subsequente o aquecimento foi realizado e o garfo levado em boca com o clone para o registro das cúspides dos molares e bordas incisais dos dentes anteriores. Em seguida, deu-se início a montagem do arco facial ajustando os parafusos de fixação do mesmo (figura 10). Após a obtenção dos registros, confeccionou-se a base com silicone de condensação pesado (Zetaplus ${ }^{\circledR}$, Zhermack, Itália) e o plano de orientação superior foi montado no ASA (figura 11).

Figura 10: Montagem do arco facial.

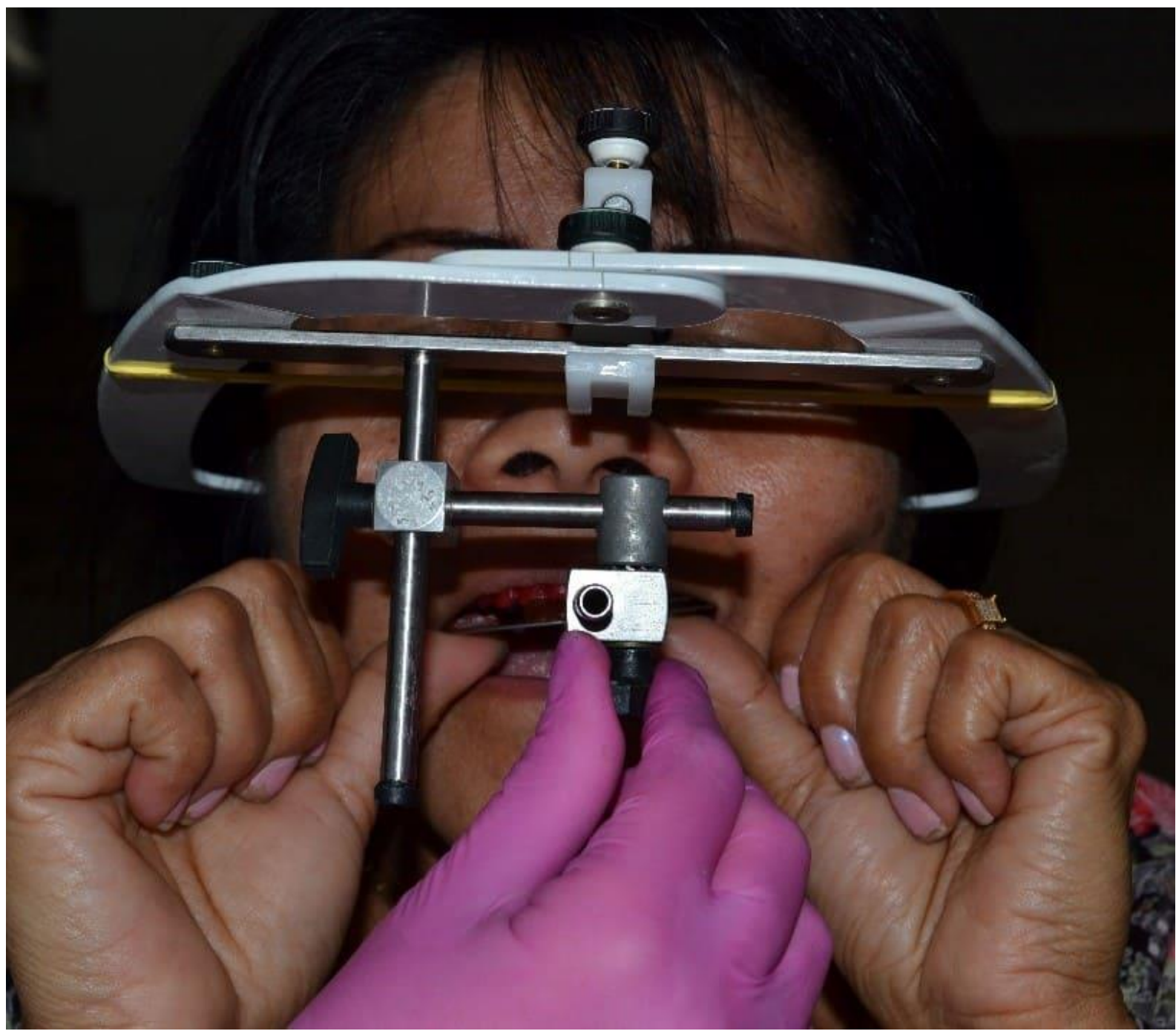

Fonte: Os autores (2020). 
Figura 11: Modelo superior montado no ASA.

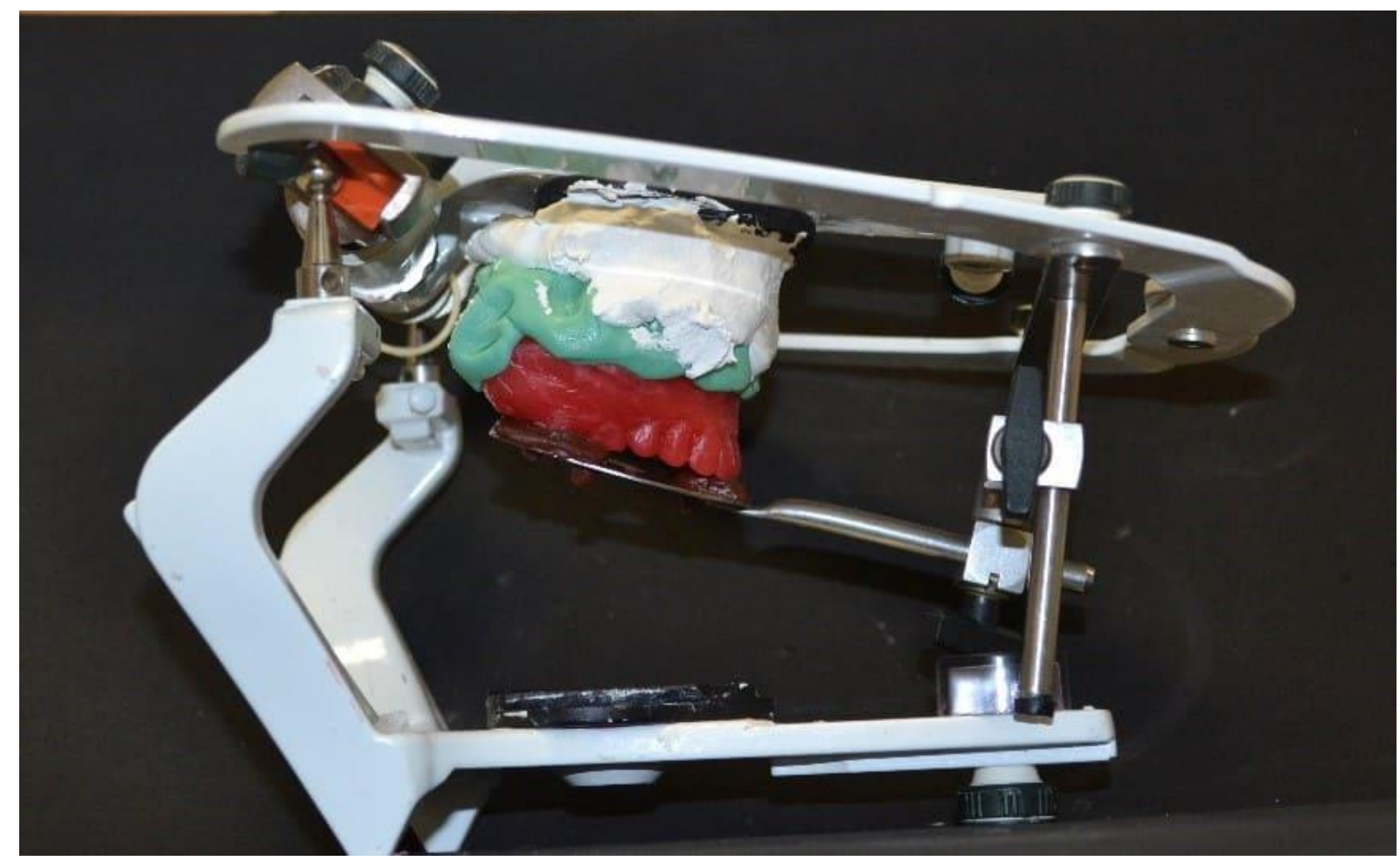

Fonte: Os autores (2020).

Posteriormente, foi produzida a moldagem anatômica da arcada inferior com alginato (Jeltrate dustless ${ }^{\circledR}$, Dentsply, Argentina) (figura 12) e sucedida pela confecção do modelo de estudo em gesso tipo IV (Durone ${ }^{\circledR}$, Dentsply, Argentina) e delineamento (figura 13). Nesta última realizou-se a escolha dos grampos circunferencial geminado nos dentes 44 e 45, e, grampo em T no dente 33, como conector maior selecionou-se a barra lingual. Após isso realizou-se o preparo de boca II, os nichos foram confeccionados e a moldagem de trabalho com silicone de condensação (Zetaplus ${ }^{\circledR}$, Zhermack, Itália) (figura 14), a qual foi enviada para o laboratório com a finalidade de fundição da armação metálica. Após efetivar adaptação no modelo, foi desenvolvido o plano de orientação com cera 7 rosa, realizando os ajustes necessários. 
Figura 12: Molde anatômico do arco inferior.

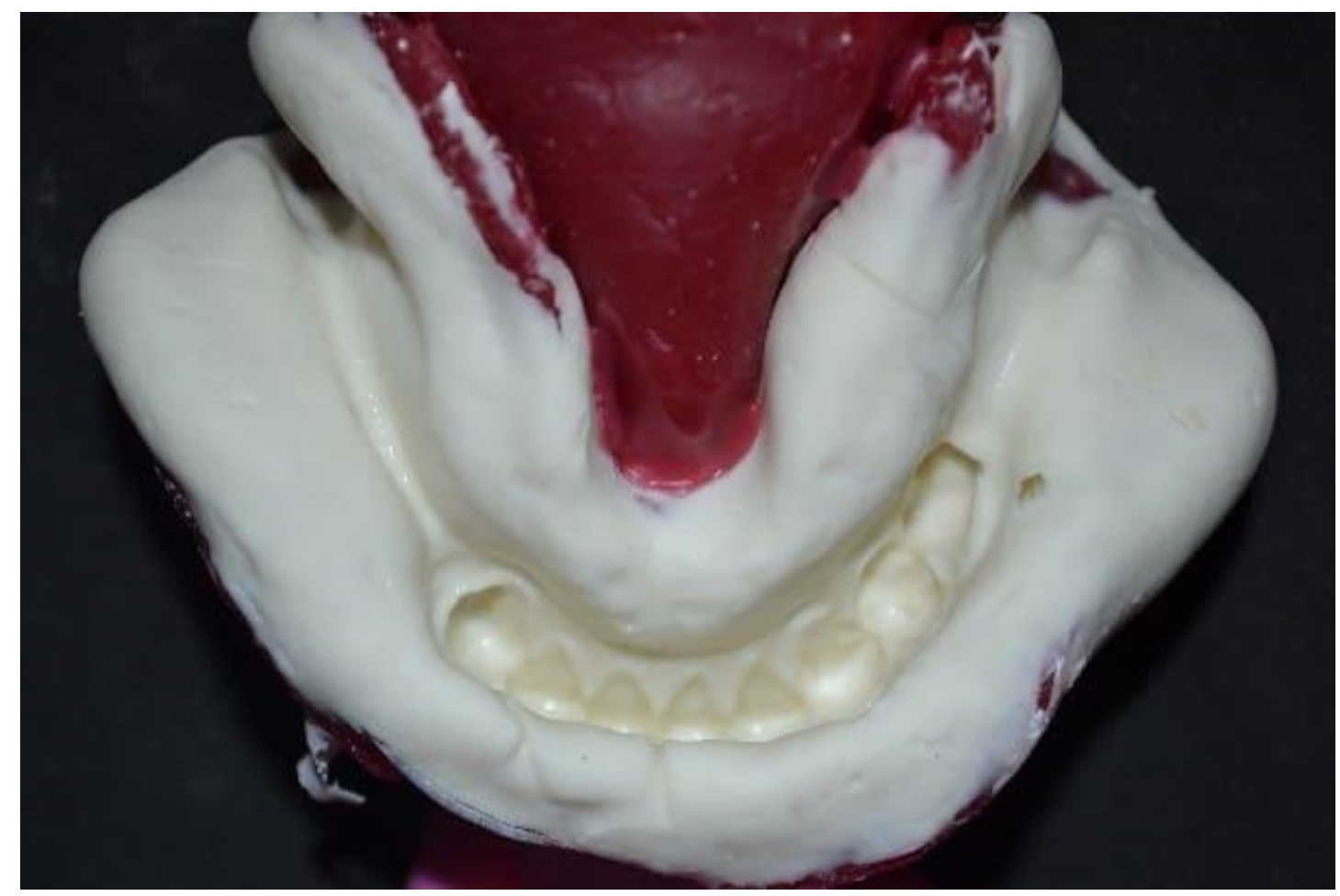

Fonte: Os autores (2020).

Figura 13: Delineamento.

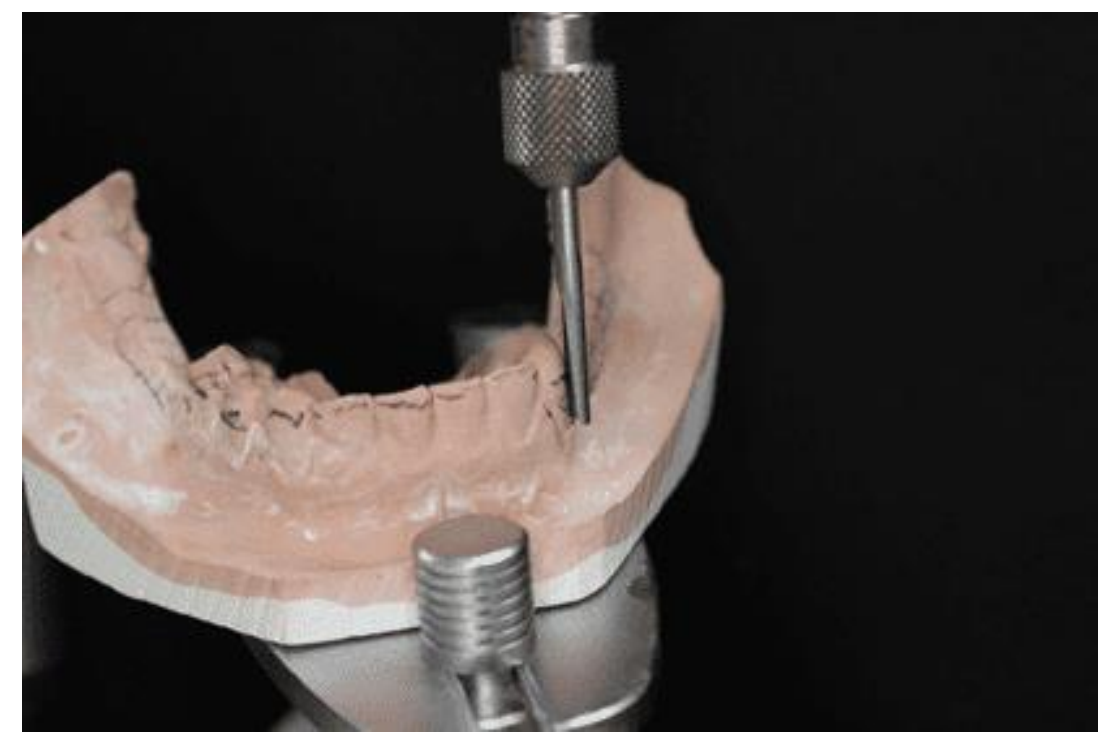

Fonte: Os autores (2020). 
Figura 14: Moldagem de trabalho do arco inferior.

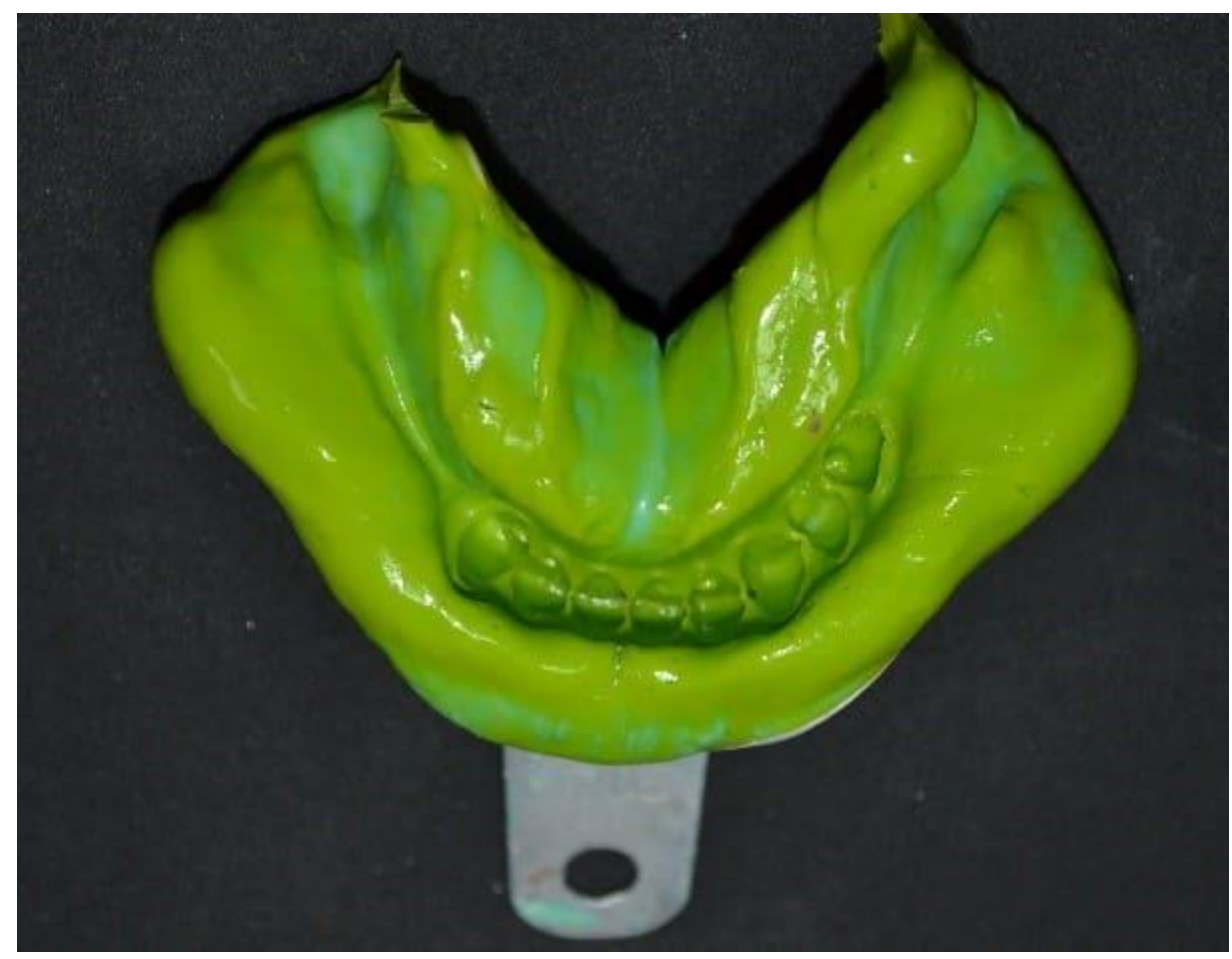

Fonte: Os autores (2020).

Em seguida, como foi utilizado o clone na arcada superior, não houve necessidade de realizar ajustes, então determinou-se a dimensão vertical e registro na posição de relação cêntrica. Então, os planos de orientação foram fixados com o auxílio de grampos para papel aquecidos (figura 15), e, levados ao ASA para fixação do modelo inferior. Finalmente encaminhou-se o conjunto ao laboratório para montagem dos dentes, com esta em concluída, realizou-se a prova dos mesmos, em que se constatou não ser necessário ajustes na posição dos dentes de estoque (figura 16). A etapa seguinte consistiu no vedamento periférico com godiva bastão, o qual foi possível obter os detalhes anatômicos da área chapeável e retenção desejadas (figura 17). 
Figura 15: Grampos fixados bilateralmente.

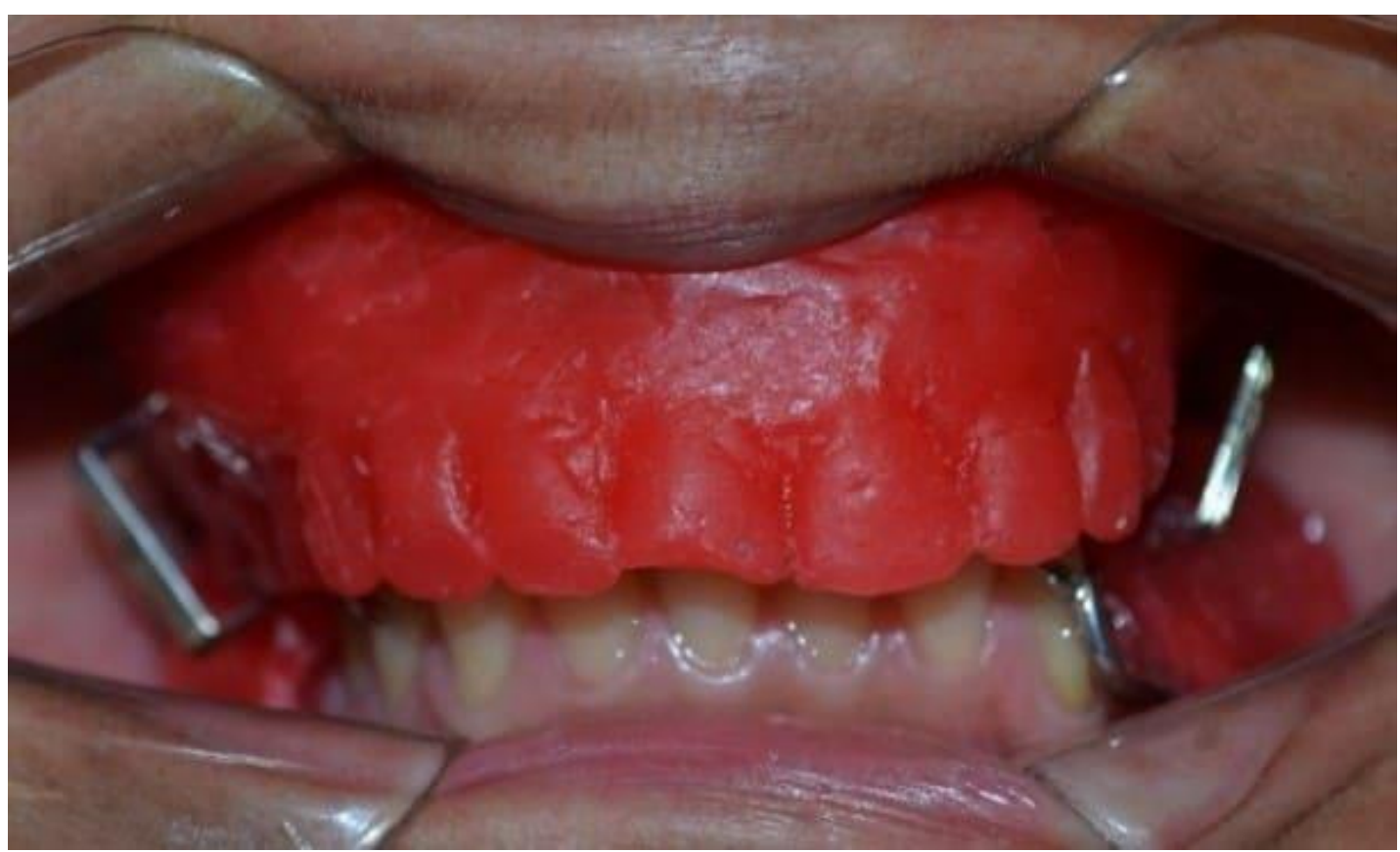

Fonte: Os autores (2020).

Figura 16: Prova da montagem dos dentes.

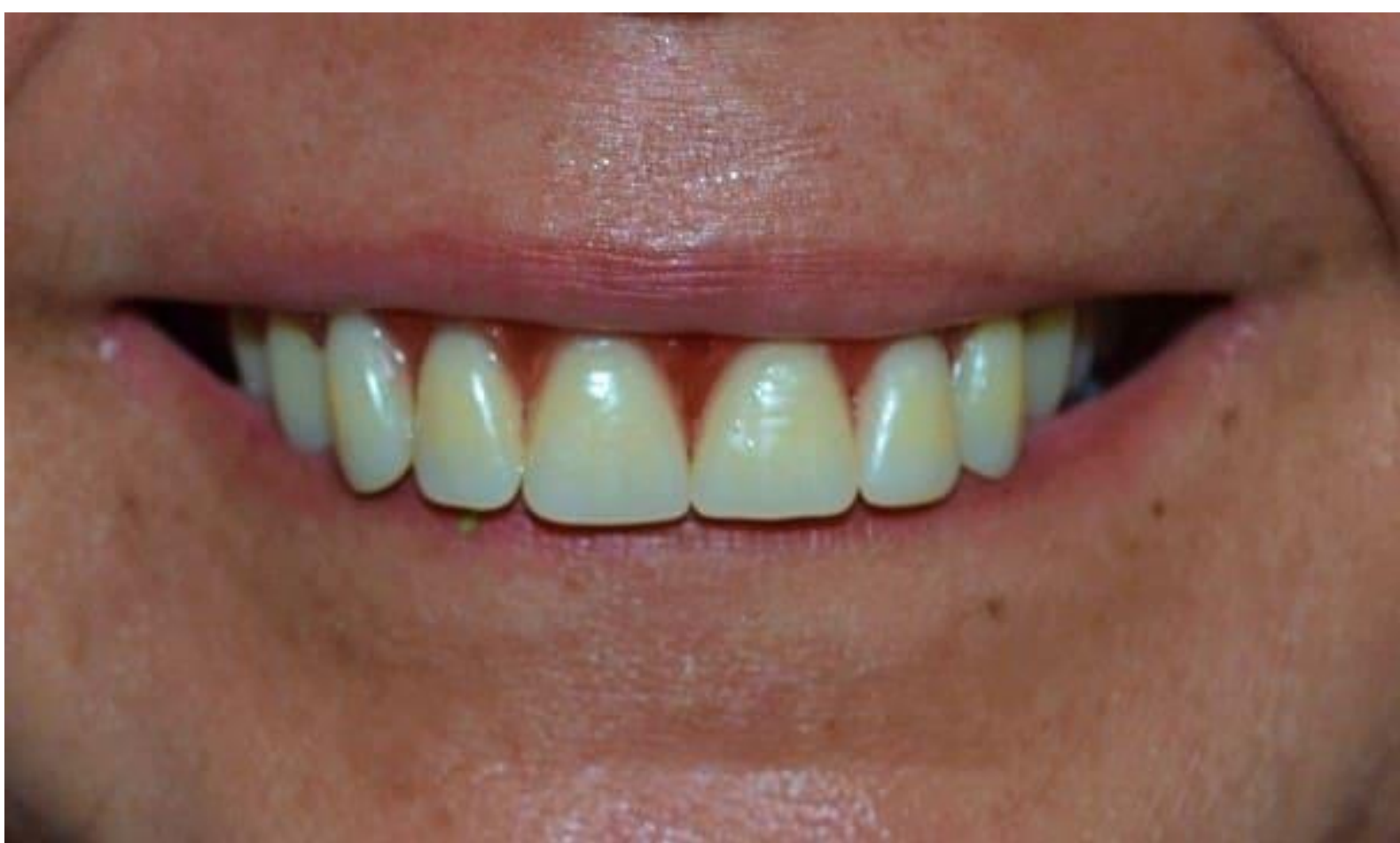

Fonte: Os autores (2020).

$\mathrm{RC}: 54698$

Disponível em: https://www.nucleodoconhecimento.com.br/odontologia/protese-bucomaxilofacial 
Figura 17: Selamento periférico finalizado.

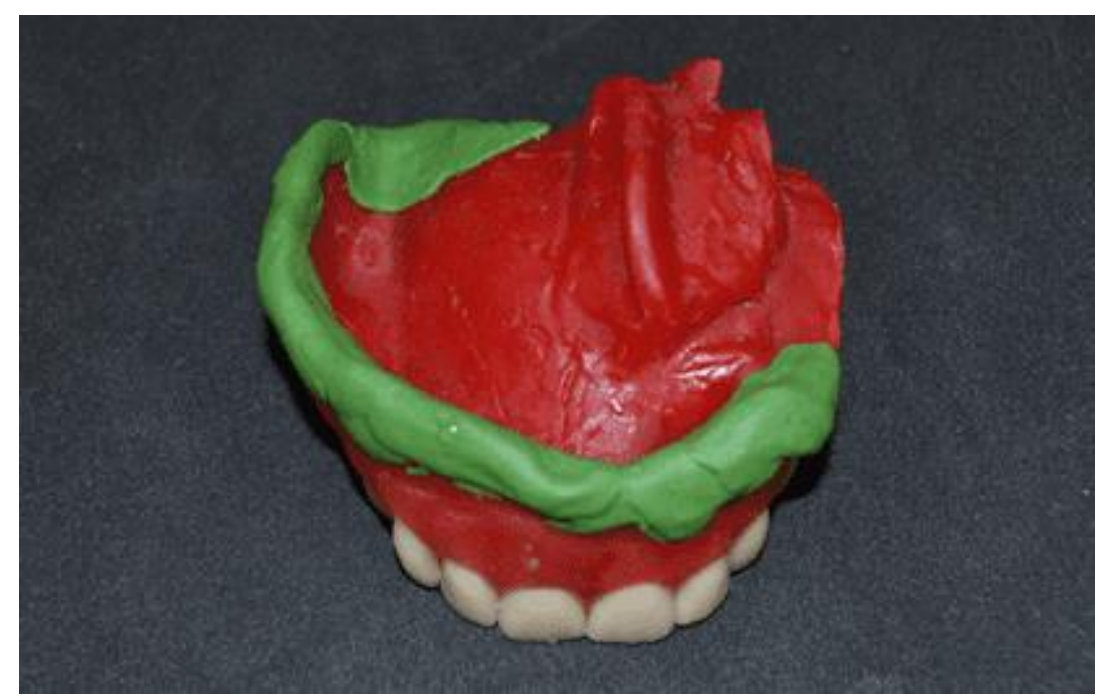

Fonte: Os autores (2020).

Dando continuidade, foi feita a última moldagem da base de prova do clone com silicone de condensação fluído (Oranwash $L^{\circledR}$, Zhermack, Itália) (figuras 18 e 19), e a paciente permaneceu com os dentes em oclusão para a moldagem (técnica da boca fechada). As bases de prova e a moldagem realizadas foram encaminhadas para acrilização.

Após acrilização da prótese obturadora, foi efetuada a instalação da mesma a fim de verificar os ajustes necessários ainda com a base de prova da PPR, não havendo necessidade de ajustes (figura 20). A PPR foi enviada para acrilização e ao término as próteses foram instaladas conferindo os ajustes novamente, constatando adaptação favorável, restabelecendo para a paciente conforto, função e estética (figura 21). 
Figura 18: Moldagem realizada com a técnica de boca fechada.

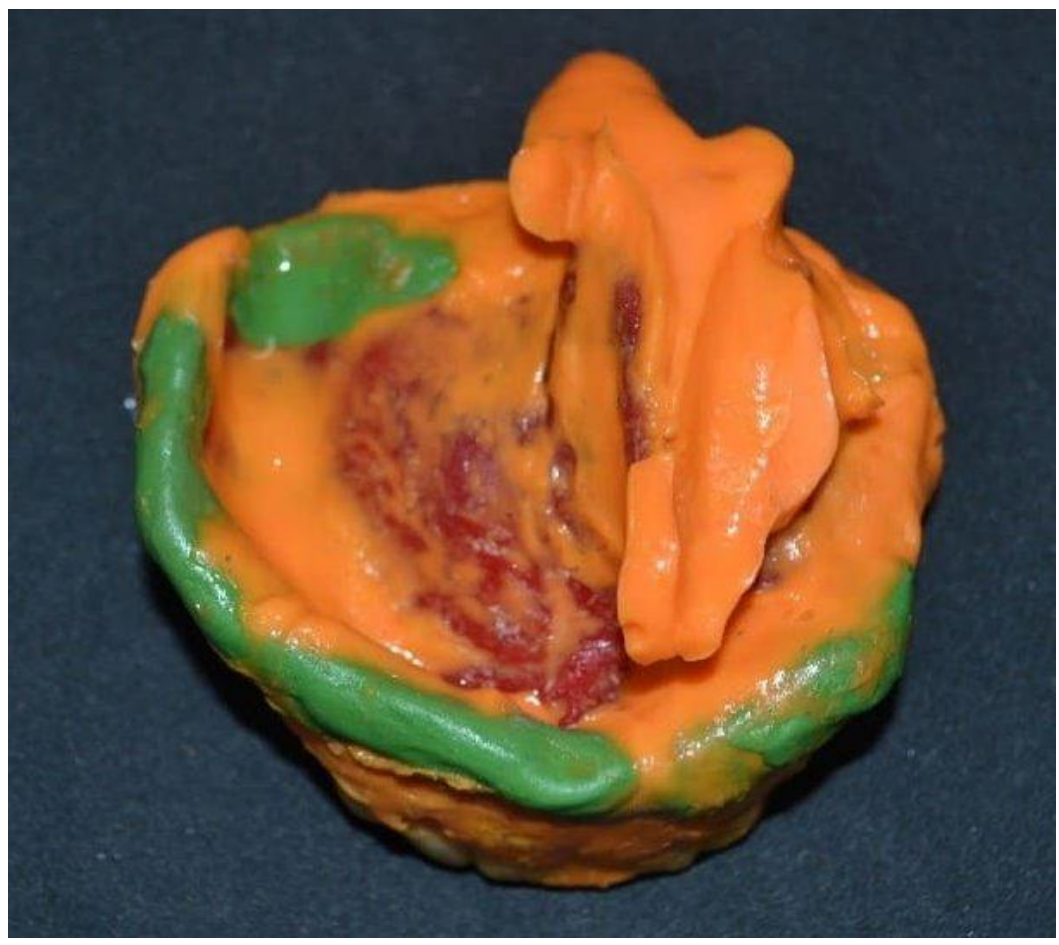

Fonte: Os autores (2020).

Figura 19: Vista lateral da moldagem funcional.

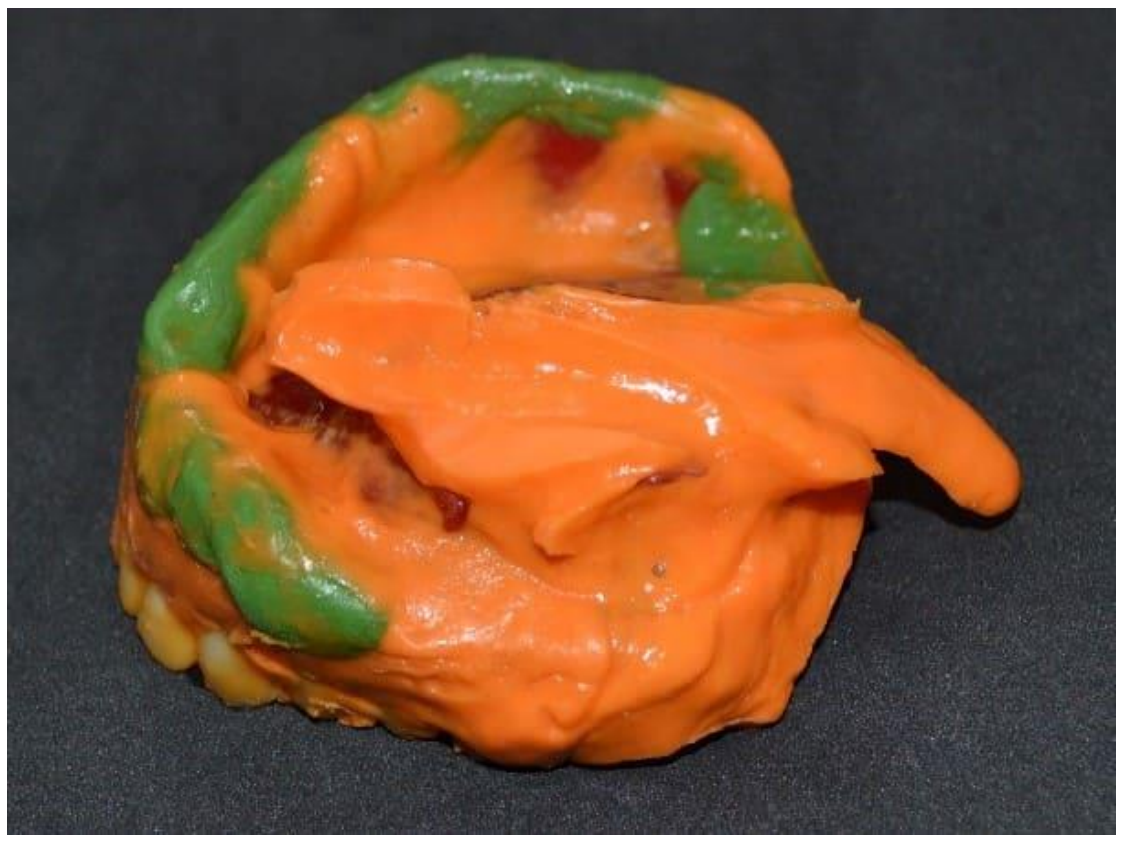

Fonte: Os autores (2020).

RC: 54698

Disponível em: https://www.nucleodoconhecimento.com.br/odontologia/protese-bucomaxilofacial 
Figura 20: Prova da prótese obturadora após acrillização com base de prova da PPR.

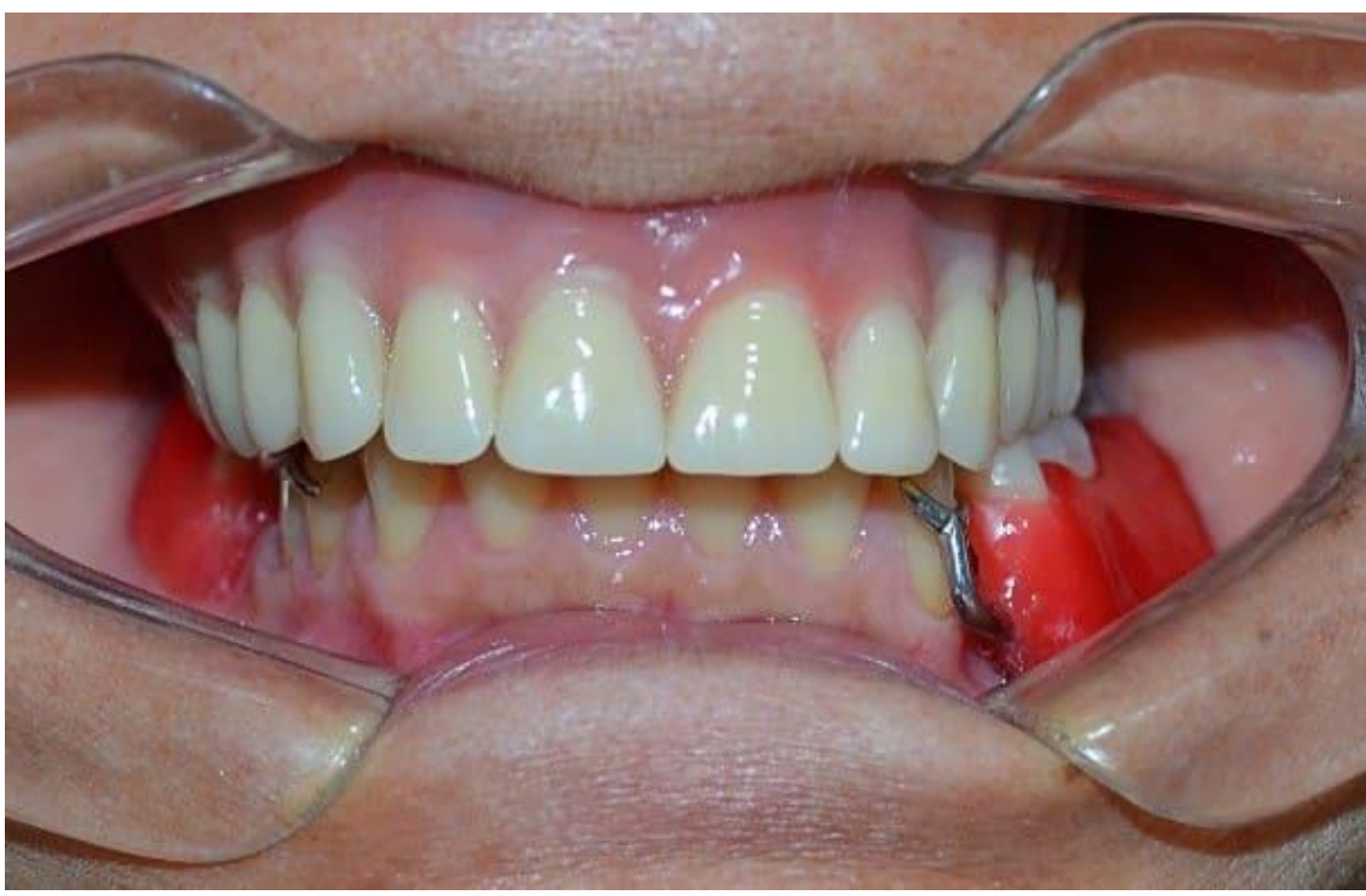

Fonte: Os autores (2020).

Figura 21: Aspecto final.

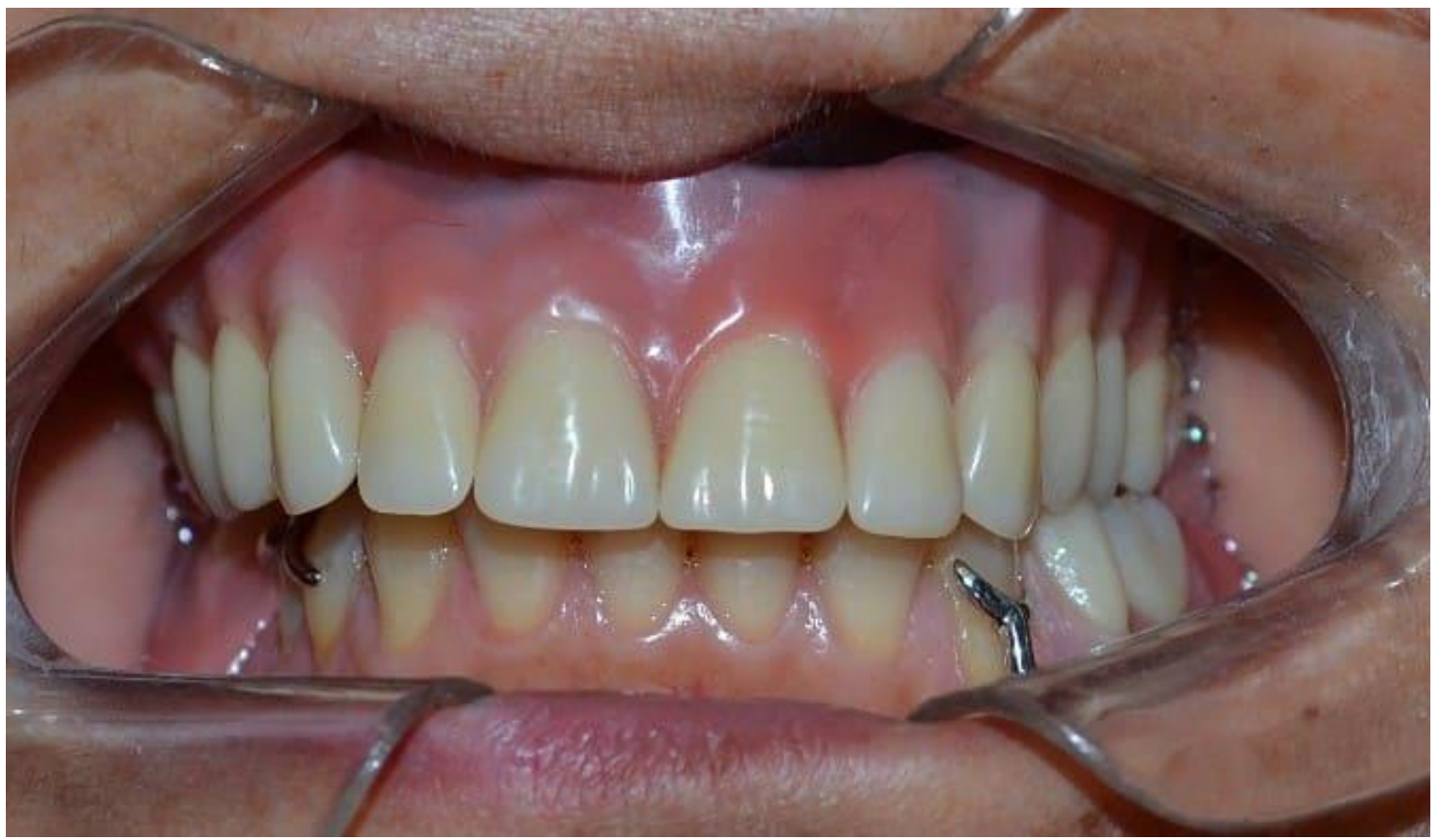

Fonte: Os autores (2020).

$\mathrm{RC}: 54698$

Disponível em: https://www.nucleodoconhecimento.com.br/odontologia/protese-bucomaxilofacial 
Ao transcorrer três meses utilizando a prótese obturadora, novos exames de controle foram realizados, sendo necessária intervenção cirúrgica imediata, pois a lesão neoplásica havia recidivado (figura 22). No retorno da paciente, após concretizar a primeira cirurgia (figura 23) e com o resultado do exame histopatológico (anexo 3) o qual indicou comprometimento das margens. A equipe médica interveio e elaborou outro plano de tratamento, que consistiu em remoção cirúrgica com ampliação de margem. Em nova consulta odontológica, doze dias após segunda cirurgia (figura 24), o exame histopatológico apontou novamente margens comprometidas (anexo 4). Assim sendo, foi planejada pela equipe médica uma cirurgia mais invasiva, podendo acarretar o comprometimento da face.

Figura 22: Recidiva da lesão.

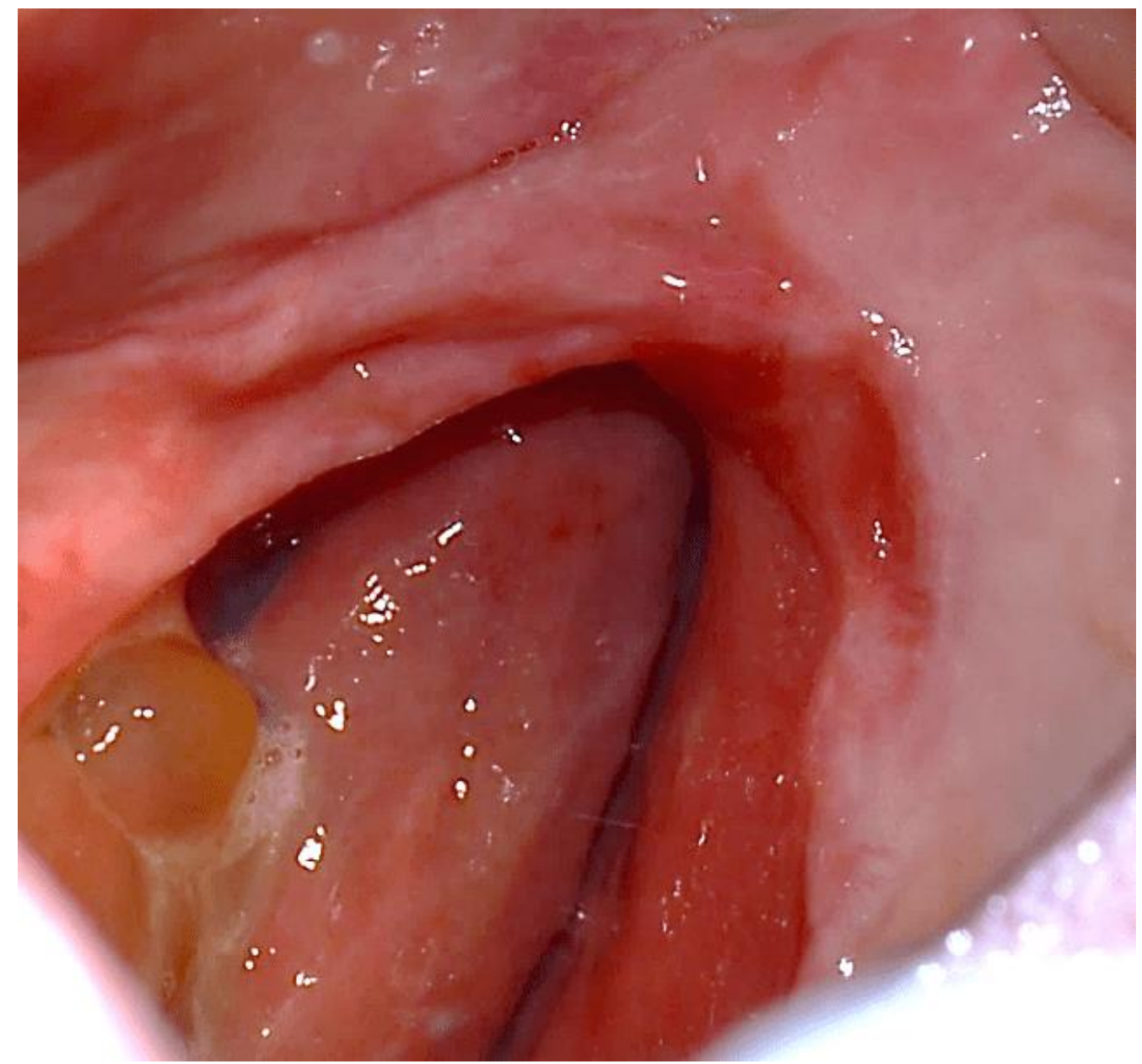

Fonte: Os autores (2020). 
Figura 23: Etapa cirúrgica 1 de remoção.

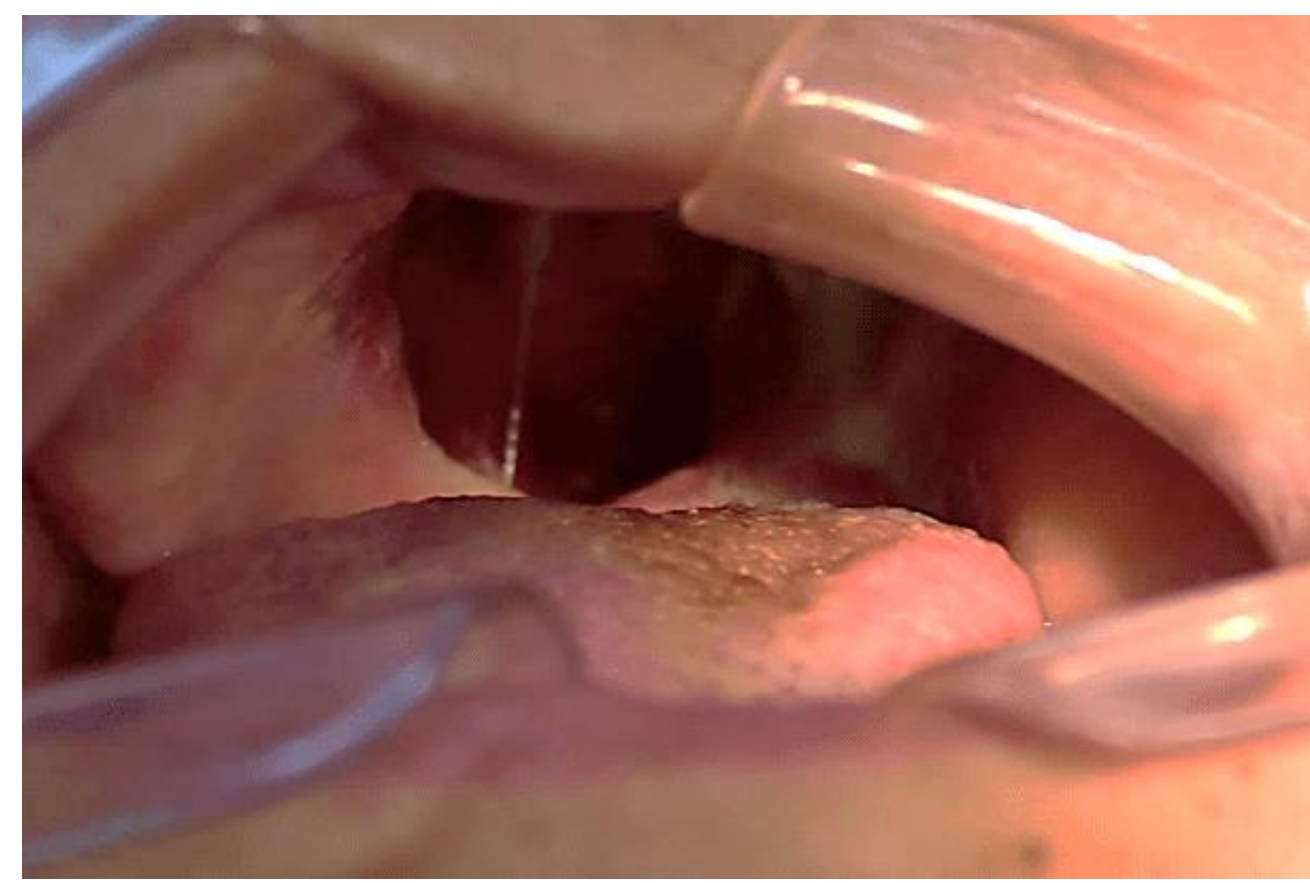

Fonte: Os autores (2020).

Figura 24: Etapa cirúrgica 2 de remoção.



Fonte: Os autores (2020).

$\mathrm{RC}: 54698$

Disponível em: https://www.nucleodoconhecimento.com.br/odontologia/protese-bucomaxilofacial 
Desta forma, um novo planejamento para reabilitação foi executado, tendo como ponto de partida a moldagem facial. A sequência clínica utilizada foi: limpeza da pele removendo maquiagem e oleosidade, proteção do cabelo com atadura, aplicação de vaselina sólida nos pelos da face, tamponamento das narinas com algodão e canudo para respiração via bucal (figura 25). Em seguida iniciou-se a manipulação do alginato (Jeltrate Dustless ${ }^{\circledR}$, Dentsply, Argentina), utilizando duas porções, sendo a proporção de água/pó 4:4. Após manipulado, foi depositado em pequenas porções na região a ser moldada com o auxílio de uma espátula (figura 26), a seguir realizou-se a retenção com algodão sobre o alginato e o gesso comum tipo II (Asfer ${ }^{\circledR}$, Brasil) foi adicionado, com a finalidade de conferir rigidez (figura 27), impedindo deformação durante sua retirada.

Figura 25: Preparo para início da moldagem facial.

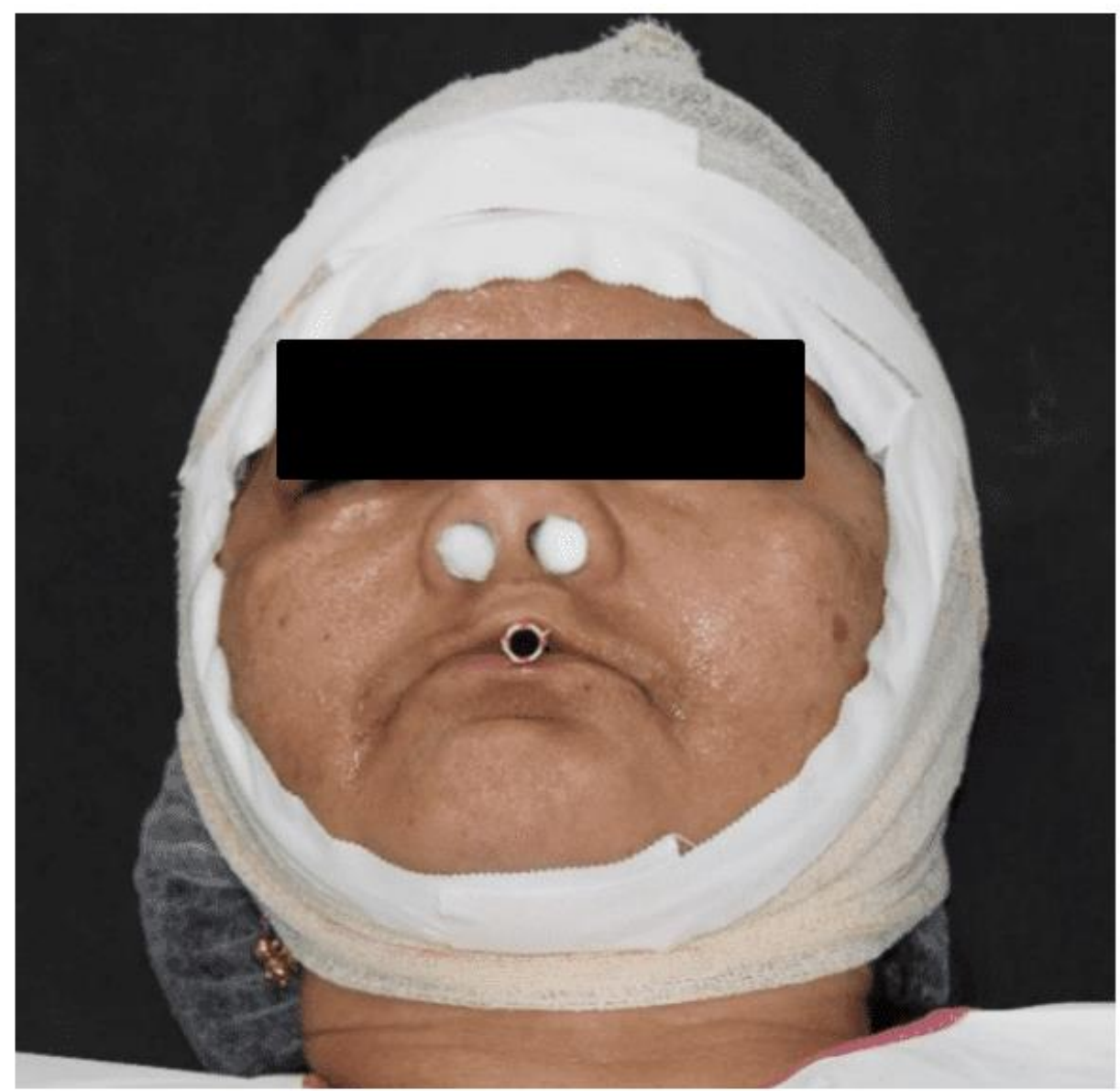

Fonte: Os autores (2020). 
Figura 26: Deposição de alginato na face.

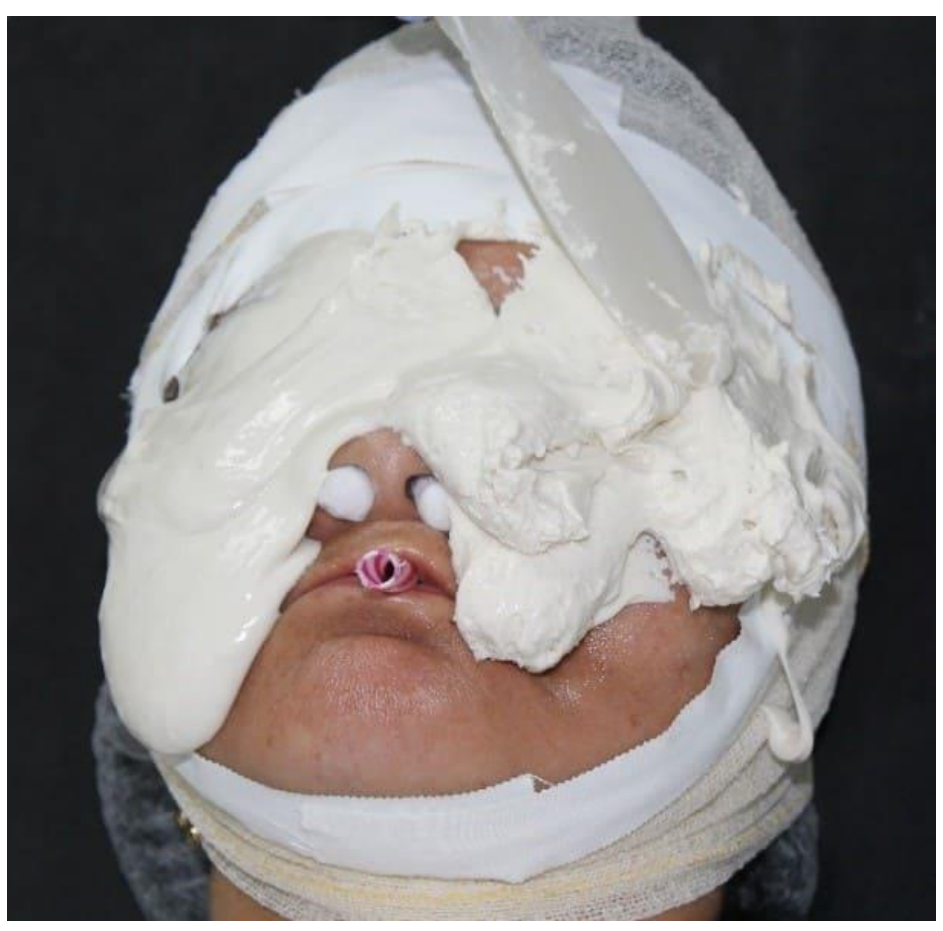

Fonte: Os autores (2020).

Figura 27: Inserção de gesso sobre a retenção.

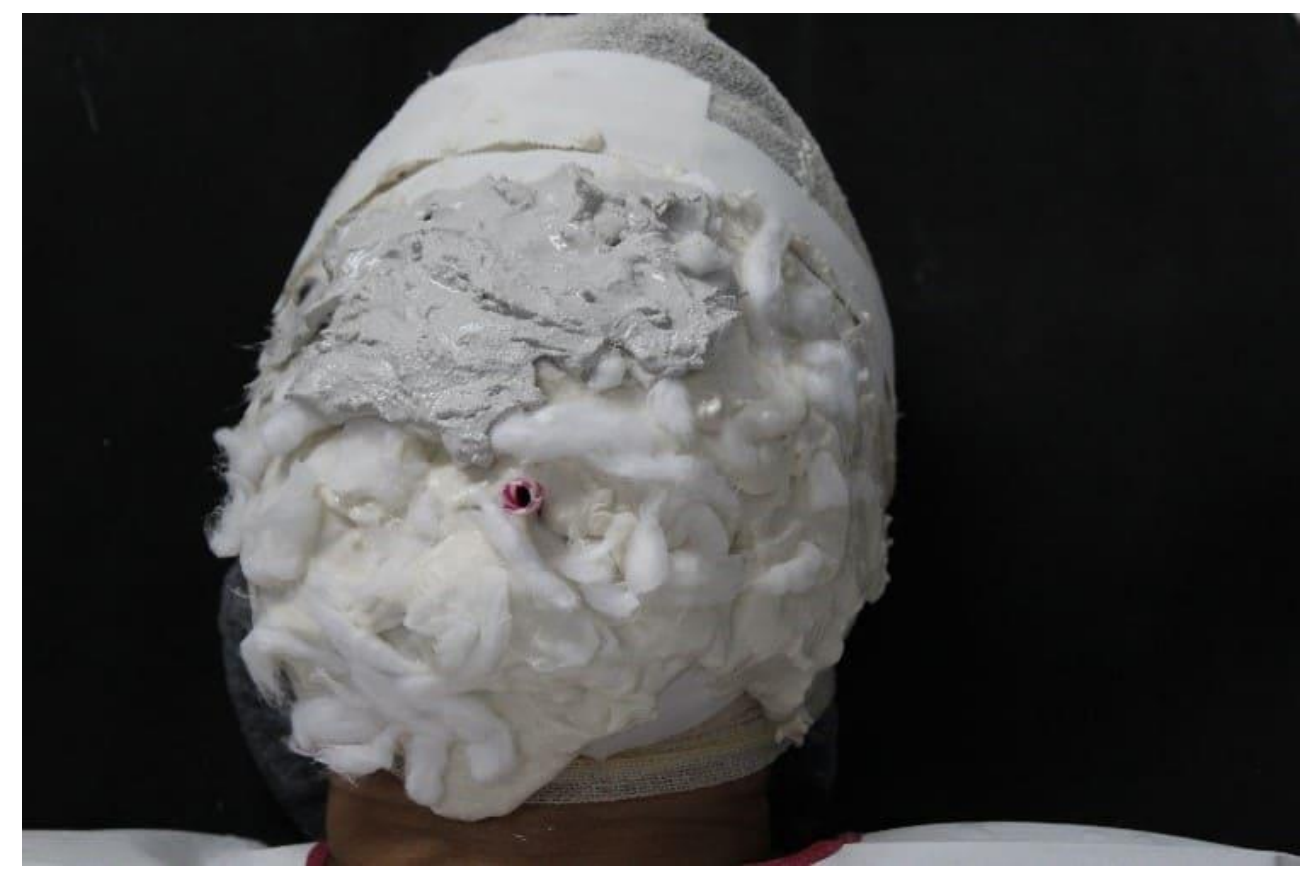

Fonte: Os autores (2020).

RC: 54698

Disponível em: https://www.nucleodoconhecimento.com.br/odontologia/protese-bucomaxilofacial 
O molde foi removido com leves movimentos, solicitando a paciente para mover os músculos da mímica (figura 28). Imediatamente após a moldagem, o molde foi preenchido com gesso tipo IV (Durone ${ }^{\circledR}$, Dentsply, Argentina) para obtenção do modelo facial. Com o auxílio de um vibrador, depositou-se o gesso sobre o molde para evitar a formação de bolhas e ao tomar presa, o modelo foi removido, conseguinte os acabamentos foram executados (figura 29). Subsequente as remoções cirúrgicas, o plano de tratamento de escolha foi a radioterapia, sendo realizada por dois meses, onde a mesma já iniciou e está sob acompanhamento médico.

Figura 28: Molde removido.

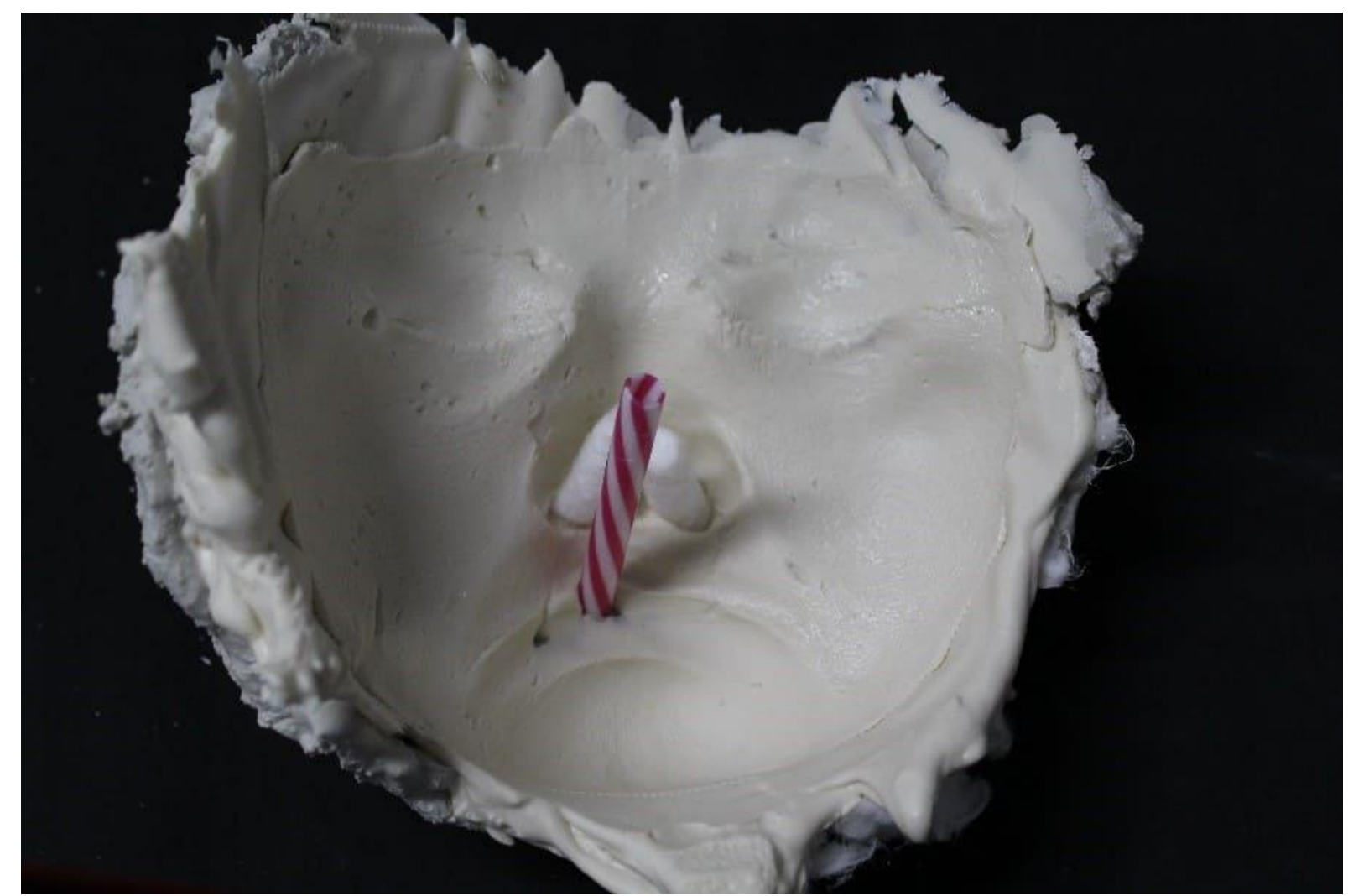

Fonte: Os autores (2020). 
Figura 29: Modelo da face finalizado.

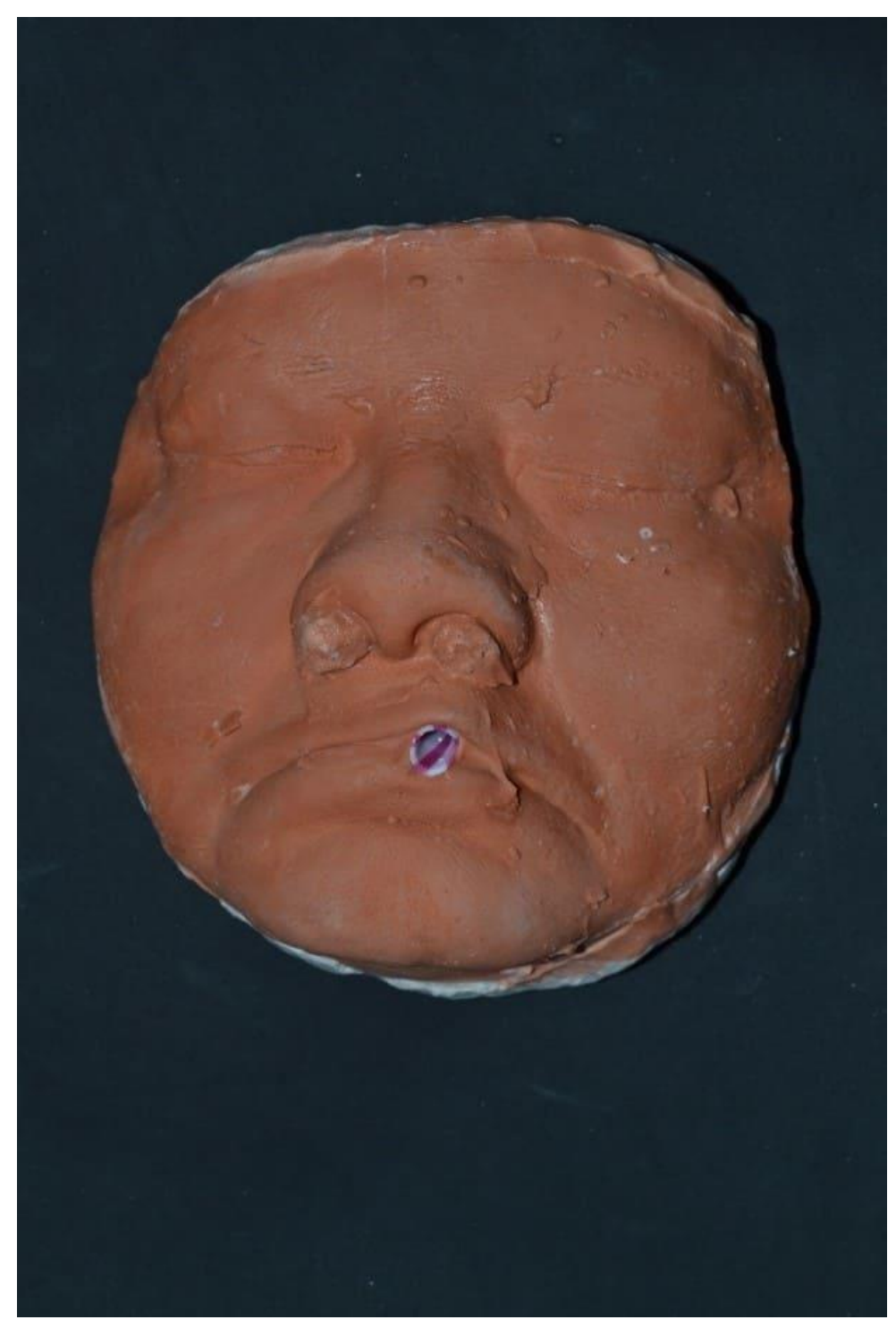

Fonte: Os autores (2020).

\section{DISCUSSÃO}

As neoplasias malignas de glândulas salivares apresentam-se de forma pouco recorrente (DE SOUSA BARBOSA et al., 2005). De acordo com estudos de Santos et al. (2003) os quais mostraram que tais neoplasias representam cerca de $2 \%$ a $6,5 \%$ dos tumores da região de cabeça e pescoço. Em relação a essas neoformações, o carcinoma mucoepidermoide é o tipo mais habitual (GIOVANINI et a., 2007), representando cerca de $5 \%$ de todos os tumores de glândulas salivares (SOUSA et

Disponível em: https://www.nucleodoconhecimento.com.br/odontologia/protese-bucomaxilofacial 
al., 2016). Alguns autores afirmam que há uma predileção em acometer mais o sexo feminino, em contrapartida alguns trabalhos apontam uma distribuição igualitária de sexo (FRANÇA et al., 2008; SOUSA et al., 2016), manifestando-se entre a $2^{\underline{a}}$ e $8^{\text {a }}$ décadas de vida com idade média de 45 anos (REZENDE, 1997). No que diz respeito as glândulas salivares menores, o palato é a região mais afetada (GIOVANINI et al., 2007; HYAM et al., 2004). No caso relatado, mesmo a paciente não apresentando nenhuma predisposição relacionada aos seus hábitos de vida, a mesma foi acometida pelo carcinoma mucoepidermoide de grau intermediário na região do palato, e, num primeiro momento após tratamento e confirmado por exames, foi considerada curada. Porém, alguns anos depois houve a recidiva da lesão, e, de acordo com estudos, relata-se que o carcinoma mucoepidermoide de grau intermediário e alto possuem índice de recidiva em 42\% no período de 10 anos (KROLLS et al., 1972).

Tem-se na literatura que as formas de tratamentos do carcinoma mucoepidermoide dependem do grau de diferenciação, presença ou não de metástases e de seu estadiamento (GIOVANINI et al., 2007; REZENDE, 1997). Sendo assim, de acordo com Guzzo et al. (2010), a radioterapia é tida como uma terapia adjuvante nesses casos e recomendada em situações de metástase, alto grau histológico e margens cirúrgicas comprometidas, e em circunstâncias inoperáveis, é a primeira linha de tratamento. Podendo ocorrer circunstâncias desfavoráveis como a xerostomia, mucosite, candidose e osteradionecrose. Em contrapartida, estudos feitos por Ozawa et al. (2008) denotam que pacientes com carcinoma mucoepidermoide, em que foram submetidos a radioterapia adjuvante, apresentaram pior sobrevida quando comparados a pacientes que foram somente operados. Outra terapêutica encontrada é a quimioterapia, que representa um tratamento paliativo em casos de grau alto, porém não se tem estudos definidos (ADELSTEIN et al., 2012).

Desta forma, a primeira escolha para tratamento do carcinoma mucoepidermoide é a ressecção cirúrgica com margens (BRANDWEIN et al., 2001). Em situações de grau baixo e intermediário de malignidade é indicado o tratamento cirúrgico (GIOVANINI et a., 2007). Porém, esse método de tratamento poderá resultar em mutilações temporárias ou definitivas (GUZZO et al., 2010). No caso exposto, optou-se pelo 
procedimento cirúrgico, realizando a hemimaxilectomia como primeira intervenção, e, após a recidiva, a maxilectomia total. Apesar das tentativas, a terapêutica abordada trouxe mutilações para a paciente, levando a problemas funcionais, estéticos e na qualidade de vida.

Pelo fato de o tratamento gerar mutilações, segundo Costa et al. (2010) uma alternativa para a reconstrução maxilar é através da cirurgia, porém irá depender da extensão do defeito, podendo ser utilizados enxertos ósseos e cartilaginosos, retalhos pediculados, retalhos livres microvascularizados, implantes intraorais, extraorais ou zigomáticos. Outro método para a reabilitação, é por intermédio da prótese obturadora, a qual tem sido considerada padrão-ouro na reconstrução palatina, pois além de proporcionar a reparação rápida do paciente, permitirá o acompanhamento mais cuidadoso em episódios de recidiva (DEPPRICH et al., 2011). É recomendada para situações onde a cirurgia para fechamento do defeito é contraindicada, casos de extensão da mutilação, idade do paciente e em situações de indícios para recidiva da lesão (SANTOS et al., 2003). Diante disso, o tratamento de escolha para a paciente foi o conservador por meio da prótese obturadora, a qual foi uma alternativa favorável, pois foi possível fazer o acompanhamento e detectar a recidiva da lesão.

Para a confecção do obturador palatino a literatura dispõe de um sistema mais rápido e efetivo denominado Computer Aided Design-Computer Aided Manufacturing (CADCAM) (KAWAHATA et al., 1997). Porém, devido seu alto custo, tornou-se inviável para o caso em questão, sendo o mais conveniente a técnica convencional para a elaboração da prótese obturadora. Sua confecção apresenta-se de forma complexa, e qualquer procedimento que se possa utilizar para minimizar o sofrimento do paciente deve ser adotado. A paciente do afazia uso de prótese obturadora com problemas de retenção

Assim, pelo fato de a paciente já fazer uso de uma prótese obturadora, pode-se optar pela realização da técnica da clonagem (DA CUNHA DINIZ et al., 2015), ainda que esta estivesse sem retenção adequada por ter passado do tempo de vida útil de 3 anos (ANTUNES et al., 2008), a mesma foi corretamente construída e restabelecia espaço funcional adequado. Segundo Gomes e Castro (2009) a técnica consiste na 
realização da matriz de silicone, e a inclusão em mufla e para a duplicação dos dentes preconizam o silicone fluído, pois irá evitar a formação de bolhas e irregularidades. No caso em questão, a técnica sofreu algumas modificações feita pelos autores para garantir maior agilidade ao procedimento. O material de escolha para se obter a réplica da base foi a resina acrílica duralay, por apresentar pouca contração de polimerização. Quanto a região dos dentes, foi confeccionada com cera 7, onde na fase seguinte os dentes copiados em cera foram substituídos pelos dentes de estoque diretamente. As modificações mostraram uma boa relação custo-benefício, não necessitando da etapa laboratorial de acrilização em forno convencional ou micro-ondas para confecção do clone.

Para realização da etapa final da prótese um fator bastante relevante é a acrilização. Wu \& Schaaf (1989) mostraram que a acrilização do obturador oco diminui o peso de 33,06 para $6,55 \%$, dependendo do tamanho do defeito. As literaturas apontam que próteses mais leves proporcionam retenção e estabilidade favoráveis. Dentre suas vantagens está no auxílio da deglutição, melhora na retenção, impedimento da ultrapassagem de alimentos e líquidos através do defeito maxilar. Fatores que foram fundamentais para a escolha da acrilização da prótese em evidência.

Através dos exames histopatológicos das últimas cirurgias realizadas na paciente, que apontaram comprometimento das margens, planejou-se uma cirurgia mais invasiva pelos seus médicos, podendo comprometer estruturas nobres de sustentação da face. Dessa forma, foi proposta a moldagem facial, sendo como um guia para possível reabilitação estético-funcional, após procedimento cirúrgico inavasivo. Os materiais descritos na literatura para confecção da moldagem facial são os elastômeros, hidrocoloides e gessos (AQUINO et al., 2012). A técnica eleita é bastante usual, de baixo custo e fácil execução, o material de escolha para o caso foi o hidrocoloide irreversível e gesso. Alsiyabi e Minsley (2006) citam que a técnica convencional utilizando hidrocoloide irreversível pode resultar em imprecisão e distorção da moldagem. Então, os autores propõem a utilização do silicone, o qual irá conferir redução na confecção clínica e pelo fato do material apresentar estabilidade dimensional, resistência a deformação e alta resistência ao rasgamento. Por outro 
lado, a principal desvantagem é o custo elevado do material. Sendo assim, a moldagem facial realizada com hidrocoloide irreversível demonstrou-se eficaz, sem distorções e custo baixo.

\section{CONCLUSÃO}

A prótese obturadora é uma alternativa eficaz na reabilitação de pacientes submetidos a ressecções cirúrgicas, as quais resultaram em mutilações. Sendo assim, a escolha pela técnica da clonagem com algumas modificações, nesse caso, além de melhor custo-benefício, reduziu a quantidade de etapas clínicas e laboratoriais, tendo como consequência a substituição da prótese antiga de forma mais rápida e eficaz. Além disso, é de grande relevância o papel dessa reabilitação na reintegração do indivíduo no meio biopsicossocial, o restabelecimento da função, estética e conforto. Quanto à moldagem facial, por se tratar de procedimento não invasivo, pode-se realizar previamente à cirurgia de lesões neoplásicas da região da face, pois o modelo resultante será de grande ajuda na reconstrução protética futura.

\section{REFERÊNCIAS}

ADELSTEIN, David J. et al. Biology and management of salivary gland cancers. In: Seminars in radiation oncology. WB Saunders, 2012. p. 245-253.

ALSIYABI, Abdullah S.; MINSLEY, Glenn E. Facial moulage fabrication using a twostage poly (vinyl siloxane) impression. Journal of Prosthodontics: Implant, Esthetic and Reconstructive Dentistry, v. 15, n. 3, p. 195-197, 2006.

AQUINO, Luana Maria Martins de et al. Técnicas de moldagem da máscara facial. Revista de Odontologia da UNESP, v. 41, n. 6, p. 438-441, 2012.

ANTUNES, Antonio Azoubel et al. Utilização de implantes ósseointegrados para retenção de próteses buco-maxilo-faciais: revisão da literatura. Rev cir traumatol bucomaxilo-fac, v. 8, n. 2, p. 9-14, 2008. 
ARTOPOULOU, Ioli loanna et al. Effects of sociodemographic, treatment variables, and medical characteristics on quality of life of patients with maxillectomy restored with obturator prostheses. The Journal of prosthetic dentistry, v. 118, n. 6, p. 783-789. e4, 2017.

BADADARE, Mokshada M. et al. Comparison of obturator prosthesis fabricated using different techniques and its effect on the management of a hemipalatomaxillectomy patient. Case Reports, v. 2014, p. bcr2014204088, 2014.

BRANDWEIN, Margaret S. et al. Mucoepidermoid carcinoma: a clinicopathologic study of 80 patients with special reference to histological grading. The American journal of surgical pathology, v. 25, n. 7, p. 835-845, 2001.

CAMPANA, Igor Gusmão; GOIATO, Marcelo Coelho. Tumores de cabeça e pescoço: epidemiologia, fatores de risco, diagnóstico e tratamento. Revista Odontológica de Araçatuba, p. 20-31, 2013

CASTRO, Osmar; GOMES, Tomaz. Execução da clonagem até a instalação da prótese. In: CASTRO, Osmar; GOMES, Tomaz. Técnica da clonagem terapêutica em prótese total. São Paulo: Santos, 2009. p. 41-8.

COSTA, Sérgio Moreira et al. Reconstrução da maxila. Rev Bras Cir Craniomaxilofac, v. 13 , n. 3 , p. $165-8,2010$

DA CUNHA DINIZ, Alexandre et al. Duplicação rápida de prótese total: passo-a-passo. Revista Ciência Plural, v. 1, n. 3, p. 85-92, 2015.

DEPPRICH, R. et al. Evaluation of the quality of life of patients with maxillofacial defects after prosthodontic therapy with obturator prostheses. International journal of oral and maxillofacial surgery, v. 40, n. 1, p. 71-79, 2011.

DE SOUSA BARBOSA, Renata Pereira et al. Neoplasias malignas de glândulas salivares-estudo retrospectivo. Revista Odonto Ciência, v. 20, n. 50, p. 361-366, 2005. 
FRANÇA, Diurianne Caroline Campos et al. Carcinoma mucoepidermóide: relato de caso. Rev. Odontol. Araçatuba, p. 20-23, 2008.

GASTALDI, G. et al. Prosthetic management of patients with oro-maxillo-facial defects: a long-term follow-up retrospective study. Oral Implantology, v. 10, n. 3, p. 276, 2017.

GIOVANINI, Ellen Greves et al. Carcinoma mucoepidermóide de palato-descrição de um caso clínico. Revista da Faculdade de Odontologia-UPF, v. 12, n. 1, 2007.

GUZZO, Marco et al. Major and minor salivary gland tumors. Critical reviews in oncology/hematology, v. 74, n. 2, p. 134-148, 2010.

HYAM, D. M.; VENESS, M. J.; MORGAN, G. J. Minor salivary gland carcinoma involving the oral cavity or oropharynx. Australian dental journal, v. 49, n. 1, p. 16-19, 2004.

KAWAHATA, N. et al. Trial of duplication procedure for complete dentures by CAD/CAM. Journal of oral rehabilitation, v. 24, n. 7, p. 540-548, 1997.

KROLLS, Sigurds O.; TRODAHL, John N.; BOYERS, Col Robert C. Salivary gland lesions in children. A survey of 430 cases. Cancer, v. 30, n. 2, p. 459-469, 1972.

LIKHTEROV, llya et al. Locoregional recurrence following maxillectomy: implications for microvascular reconstruction. The Laryngoscope, v. 127, n. 11, p. 2534-2538, 2017.

OZAWA, Hiroyuki et al. Mucoepidermoid carcinoma of the head and neck: clinical analysis of 43 patients. Japanese journal of clinical oncology, v. 38, n. 6, p. 414-418, 2008.

RETTIG, Eleni M.; D'SOUZA, Gypsyamber. Epidemiology of head and neck cancer. Surgical Oncology Clinics, v. 24, n. 3, p. 379-396, 2015. 
REZENDE, José Roberto Vidulich. Prótese nas grandes perdas da maxila. In: REZENDE, José Roberto Vidulich et al. Fundamentos da prótese buco-maxilo-facial. 1997.

SANTOS, Gilda da Cunha et al. Neoplasias de glândulas salivares: estudo de 119 casos. Jornal Brasileiro de Patologia e Medicina Laboratorial, v. 39, n. 4, p. 371-375, 2003.

SOUSA, Andréa Rodrigues de et al. Perfil clínico-epidemiológico de pacientes com câncer de cabeça e pescoço em hospital de referência. Rev. Soc. Bras. Clín. Méd, v. 14, n. 3, p. 129-132, 2016.

WU, Yn-low; SCHAAF, Norman G. Comparison of weight reduction in different designs of solid and hollow obturator prostheses. The Journal of prosthetic dentistry, v. 62, n. 2, p. 214-217, 1989 


\section{ANEXOS}

\section{Anexo 1}

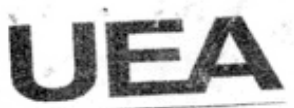

UNIVERSIDADE DO ESTADO DO AMAZONAS
LABORATÓRIO DE PATOLOGIA BUCAL

AV. CARVALHO LEAL, 1777. CACHOEIRINHA CeP: 69065-001 MANAUS-AM

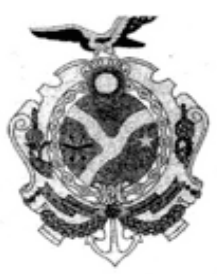

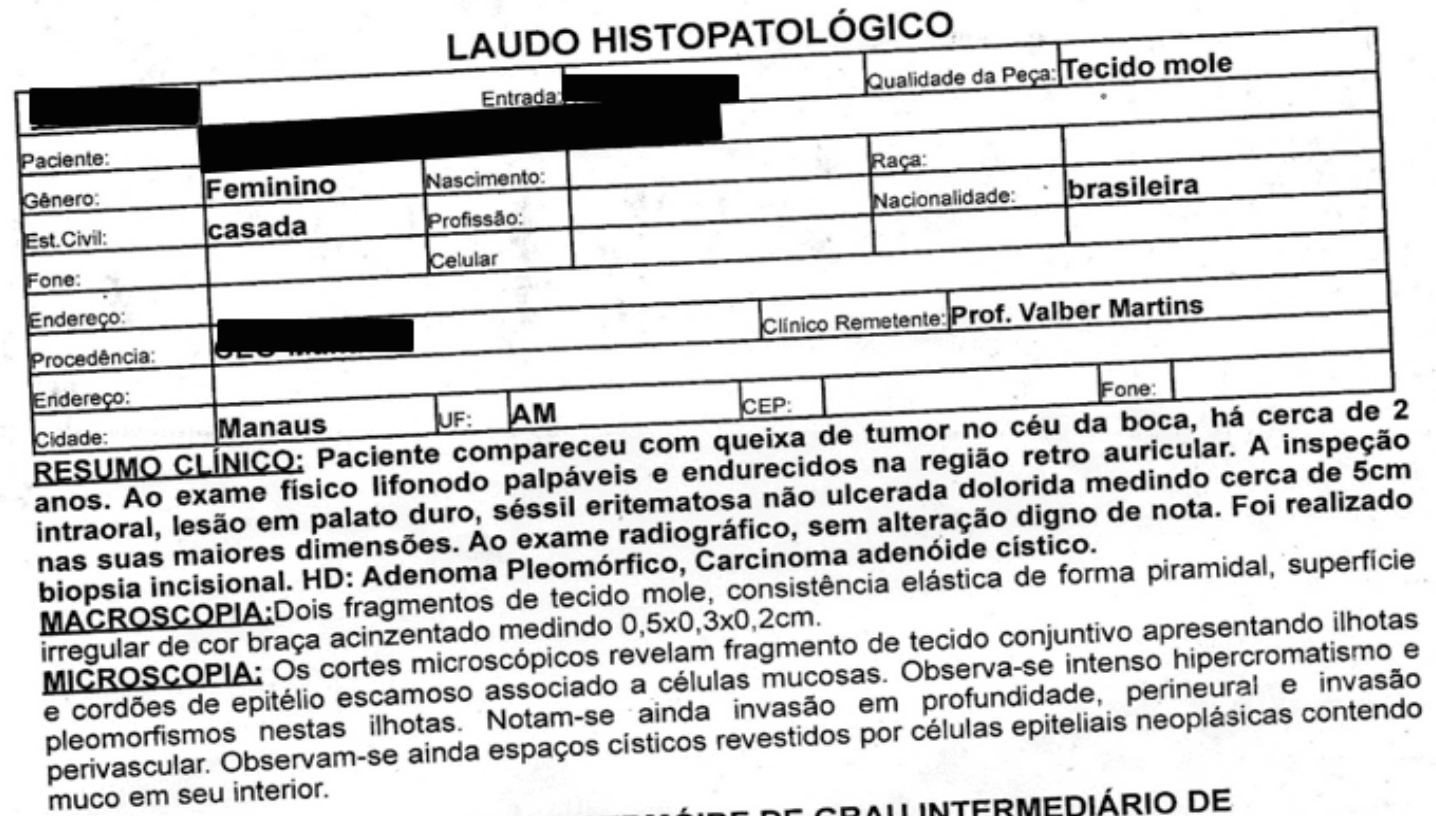

DIAGNOSTICO: CARCINOMA MUCC.

MALIGNIDADE (OMS-2005).
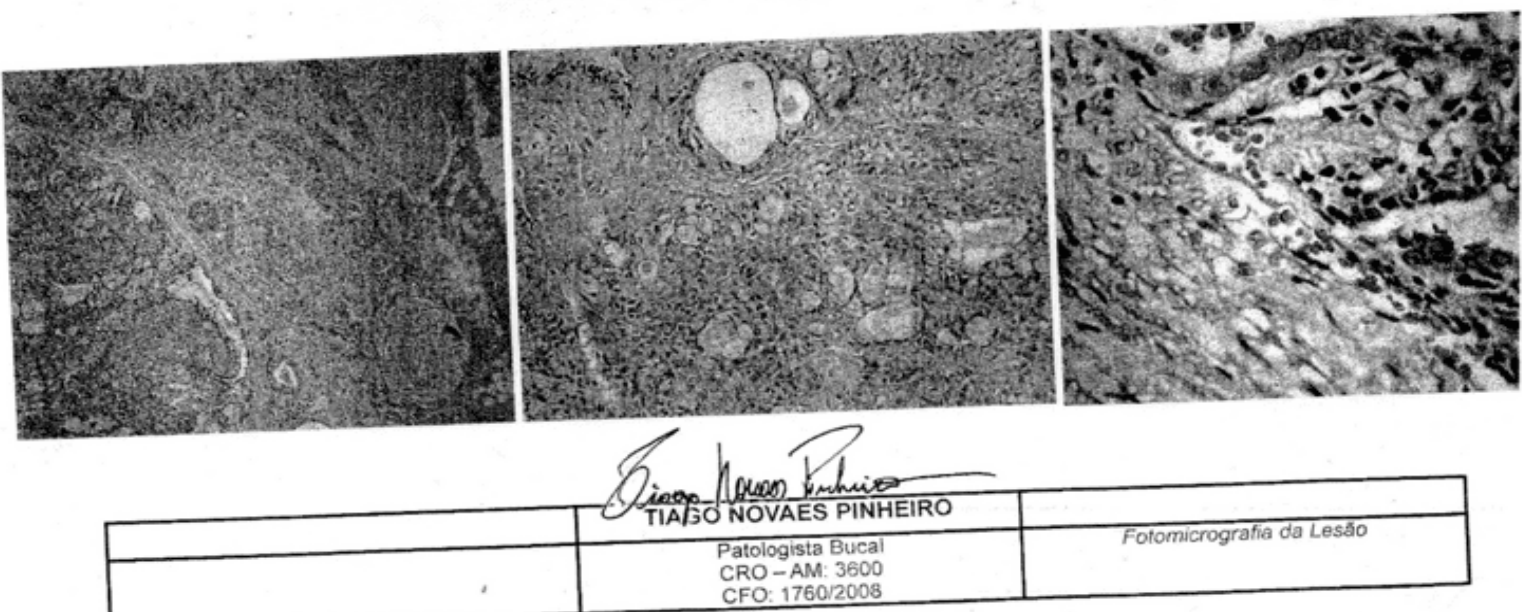


\section{Anexo 2}

FUNDAÇÃO CENTRO DE CONTROLE DE ONCOLOGIA DO ESTADO DO AMAZONAS -FCECON Rua Francisco Orellana, No 215 - Planalto, Manaus - AM - Tel.: (092) 3655-4600 Fax.: (092) 3655-4762

\section{LABORATÓRIO DE ANATOMIA PATOLÓGICA}

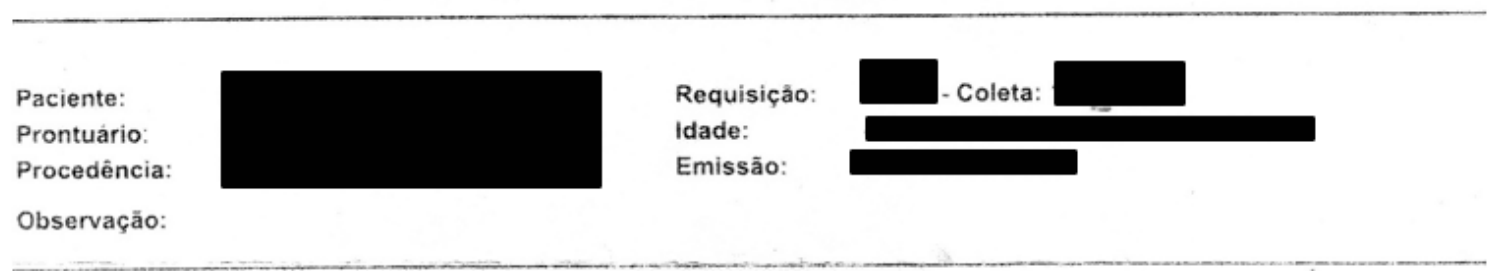

\section{Macroscopia:}

\section{8/13 / (Lesão de palato duro):}

Recebido em formol. 02 fragmentos irregulares brancacentos, elásticos, medindo $0,5 \times 0.4 \times 0,2 \mathrm{~cm}$. Todo material foi selecionado em secções párá exame histopatológico.

Dra. Rosilene Viana de Andrade

\section{Conclusão:}

Os cortes mostram biópsia de palato duro. Na lâmina própria infiltrado inflamatório constituído por plasmócitos, granulócitos neutrófi linfócitos e histiócitos, a par de proliferação vascular.

Sugestivo de precesso inflamatório crônico inespecifico. Ausêneia de malignidade na amostra cxaminada.

Dra. Rosilene Viana de Andrade

Data: $29 / 04 / 2013$

Rosilene Viana de Andrade 


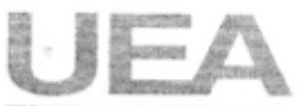

UNIVERSIDADE DO ESTADO DO AMAZONAS
LABORATÓRIO DE PATOL OGLA BUCAL

AV CARVALHO LEAL, 1777 CACHOEIRINHA Cep 69065-001 MANAUS-ANG

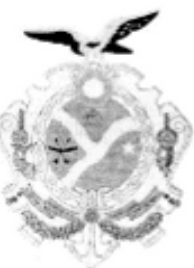

LAUDO HISTOPATOLÓGICO

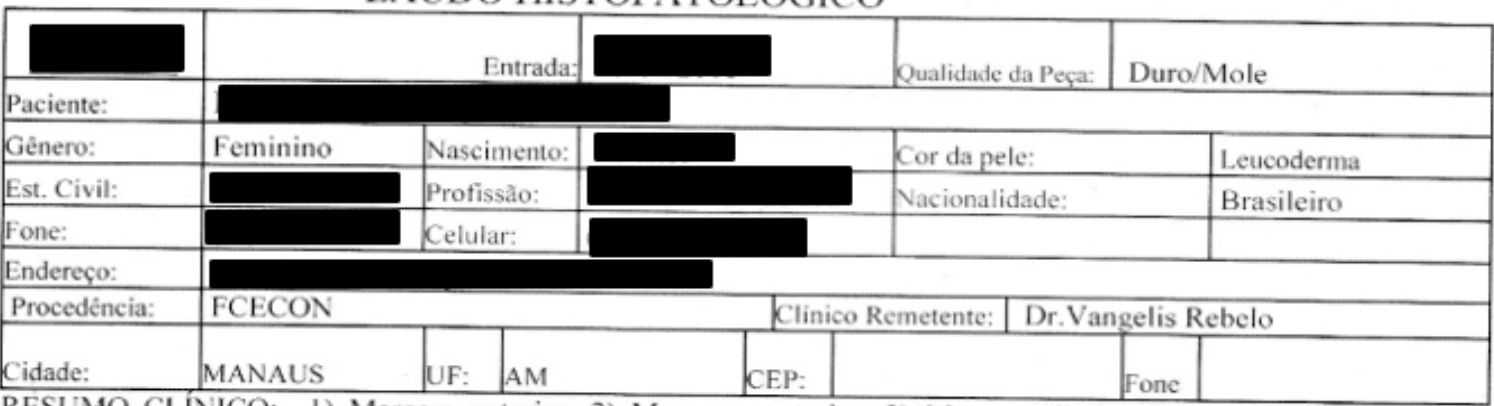

RESUMO CLÍNICO: 1) Margem anterior. 2) Margem posterior. 3) Margem direita. 4) Margem esquerda. 5) Margem superior

MACROSCOPIA: Vidro 1: Dois fragmentos de tecido duro/mole, de consistência duro/mole, de forma e superficie irregular,de coloração acinzentada medindo $3,5 \times 2,0 \times 0,8 \mathrm{~cm}$, margem anterior. (3F/2B/TM)

Vidro 2: Um fragmento de tecido mole/duro, consistência duro/mole, de forma e superficie irregular, de coloração acastanhada, medindo $3,2 \times 2,2 \times 1,2 \mathrm{~cm}$, margem posterior. $(12 \mathrm{~F} / 5 \mathrm{~B} / \mathrm{TM})$

Vidro 3: Dois fragmentos de tecido mole, de consistência mole, de forma e superficie irregular, de coloração acizentada, medindo $3,3 \times 1,4 \times 0,6 \mathrm{~cm}$, margem direita. ( $\mathrm{F} / 1 \mathrm{~B} / \mathrm{TM})$

Vidro 4: Um fragmento de tecido mole, de consistência mole, de forma e superficie irregular, de coloração brancacenta, medindo $2,3 \times 0,7 \times 0,8 \mathrm{~cm}$, margem esquerda.(4F/2B/TM)

Vidro 5: Vários fragmentos de tecido duro/mole, de consistência dura/mole, de forma e superfïcie irregular, medindo $3 \times 3,5 \times 0,5 \mathrm{~cm}$, margem superior.(VF/3B/TM)

MICROSCOPIA: Avaliação de margens de lesão previamente diagnosticada e confirmada por análise imunoistoquimica como CARCINOMA MUCOEPIDERMÓIDE DE GRAU INTERMEDIÁRIO (OMS 2017)

Margem anterior: Os cortes microscópicos revelam fragmento de mucosa bucal revestida por epitélio estratificado pavimentoso paraqueratinizado subjacente o tecido conjuntivo é frouxo não modelado bem organizado e vascularizado. Nos planos profundos observa-se tecido ósseo lamelar com sistema harversiano e celularidade habituais,além de espaços medulares preenchidos por tecido conjuntivo frouxo. Completa o quadro área de inserção muscular de músculo estriado esquelética de morfologia habitual.

\section{MARGEM ANTERIOR LIVRE}

Margem posterior:Os cortes microscópicos revelam fragmento de mucosa bucal revestida por epitélio estratificado pavimentoso paraqueratinizado hiperplásico. Subjacente observa-se tecido conjuntivo frouxo não modelado bem colagenizado com fragmentos de glândulas salivares mucosas apresentando área focal desorganizada por intenso infiltrado inflamatório linfoplasmocitário com extravasamento de muco associado a ductos salivares ora dilatados e rompidos, ora ectásicos. Nota-se ainda em uma das margens feixes de fibras musculares estriadas esqueléticas de aspecto habitual. No plano profundo observa-se mucosa respiratória parcialmente revestida por epitélio pseudoestratificado colunar ciliado. O tecido conjuntivo subjacente a esta porção apresenta ilhotas e lençóis de células intermediárias de núcleos pleomórficos e hipercromáticos, algumas delas formando áreas microcisticas.

\section{MARGEM POSTERIOR COMPROMETIDA (2 DOS 5 BLOCOS AVALIADOS)}

Margem direita: Os cortes microscópicos revelam fragmento de mucosa bucal revestida parcialmente por epitélio estratificado pavimentoso paraqueratinizado hiperplásico com degeneração hidrópica e deslocamento do conjuntivo subjacente. $\mathrm{O}$ tecido conjuntivo é frouxo não modelado bem colagenizado e vascularizado e apresentada em seus planos profundos lençóis e ninhos de células mioepiteliais e intermediárias se infiltradndo no tecido muscular subjacente, além de intima relação com feixes neurais.

\section{MARGEM DIREITA COMPROMETIDA}

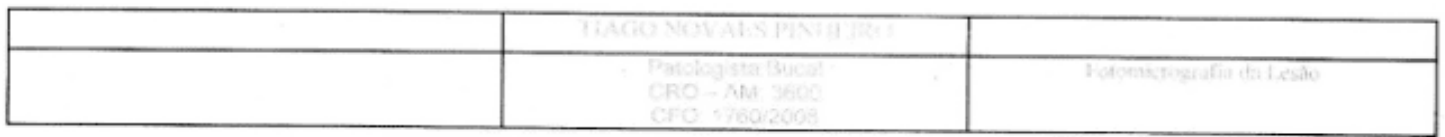




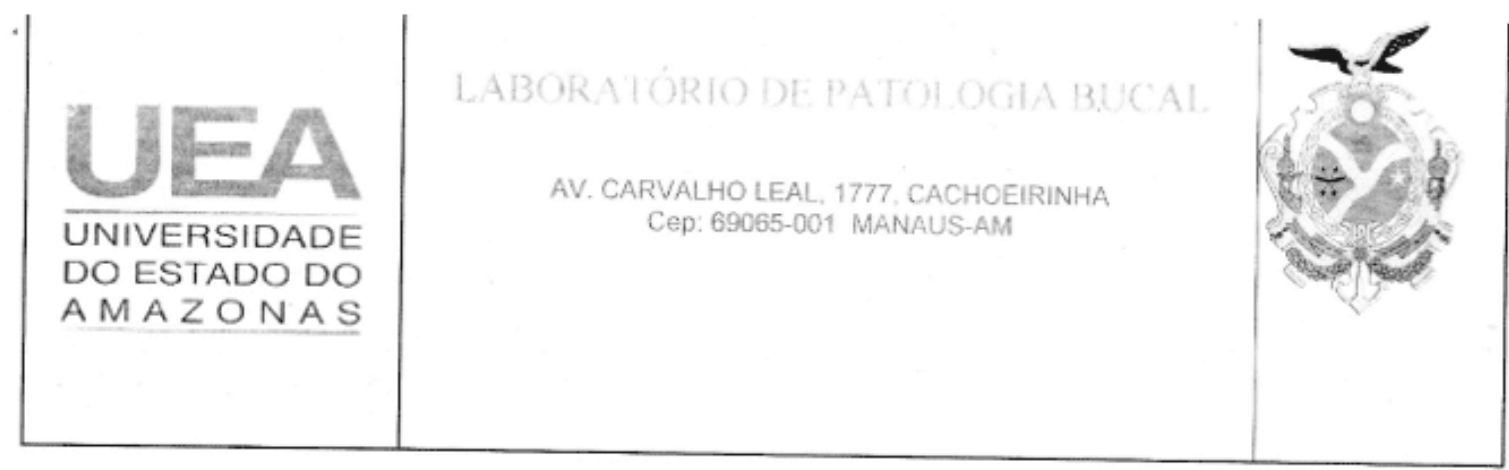

Margem esquerda: Os cortes microscópicos revelam fragmento de mucosa respiratória parcialmente revestida por epitélio pseudoestratificado colunar ciliado. O tecido conjuntivo subjacente é frouxo não modelado com moderadc infiltrado inflamatório mononuclear linfoplasmocitário difusamente distribuido na porção subepitelial. Notam-se ainda fragmentos de glândula salivar mucosa, apresentando arquitetura acinar irregular, áreas focais de intense inilftrado inflamatório mononuclear linfoplasmocitário periacinar. ductos dilatados, áreas de ectasia ductal e artefatos periféricos de alteração lítica basofilica por calor. Nota-se ainda na porção central da peça tecido ósseo lamelar celularizado de aspecto habitual. Completa o quadro a porção de mucosa bucal revestida por epitélio estratificado pavimentoso paraqueratinizado hiperplásico com degeneração hidrópica e áreas de deslocamento do conjuntivo subjacente.

\section{MARGEM ESQUERDA LIVRE}

Margem superior: Os cortes microscópicos revelam fragmento de mucosa sinusal maxilar parcialmente revestida por epitélio pseudoestratificado colunar ciliado com áreas de atrofia e de hiperplasia dispostas de forma irregular na peça. O tecido conjuntivo subjacente é frouxo não modelado apresentando mucinose dando aspecto mixóide em várias regiōes da peça. As glândulas mucosas presentes estão hipertróficas com ductos ora dilatados, ora ectásicos com áreas focais de intenso infiltrado linfoplasmocitário periacinar e periductal. Destacam-se áreas focais de aglomerados celulares formando ninhos de células mioepitelias e intermediárias por vezes de citoplasma claro e núcleo pleomórfico em regiões profundas próximas a feixes neurais. Completa o quadro rica rede vascular predominantemente capilar com congestão bem como alterações basofilicas artefatuais periféricas por calor com desorganização da arquitetura tecidual.

\section{MARGEM SUPERIOR COMPROMETIDA (1 DE 3 BLOCOS AVALIADOS).}

\section{DIAGNÓSTICO: VER DESCRICÃO}

Manaus - AM, 18 de abril de 2018.

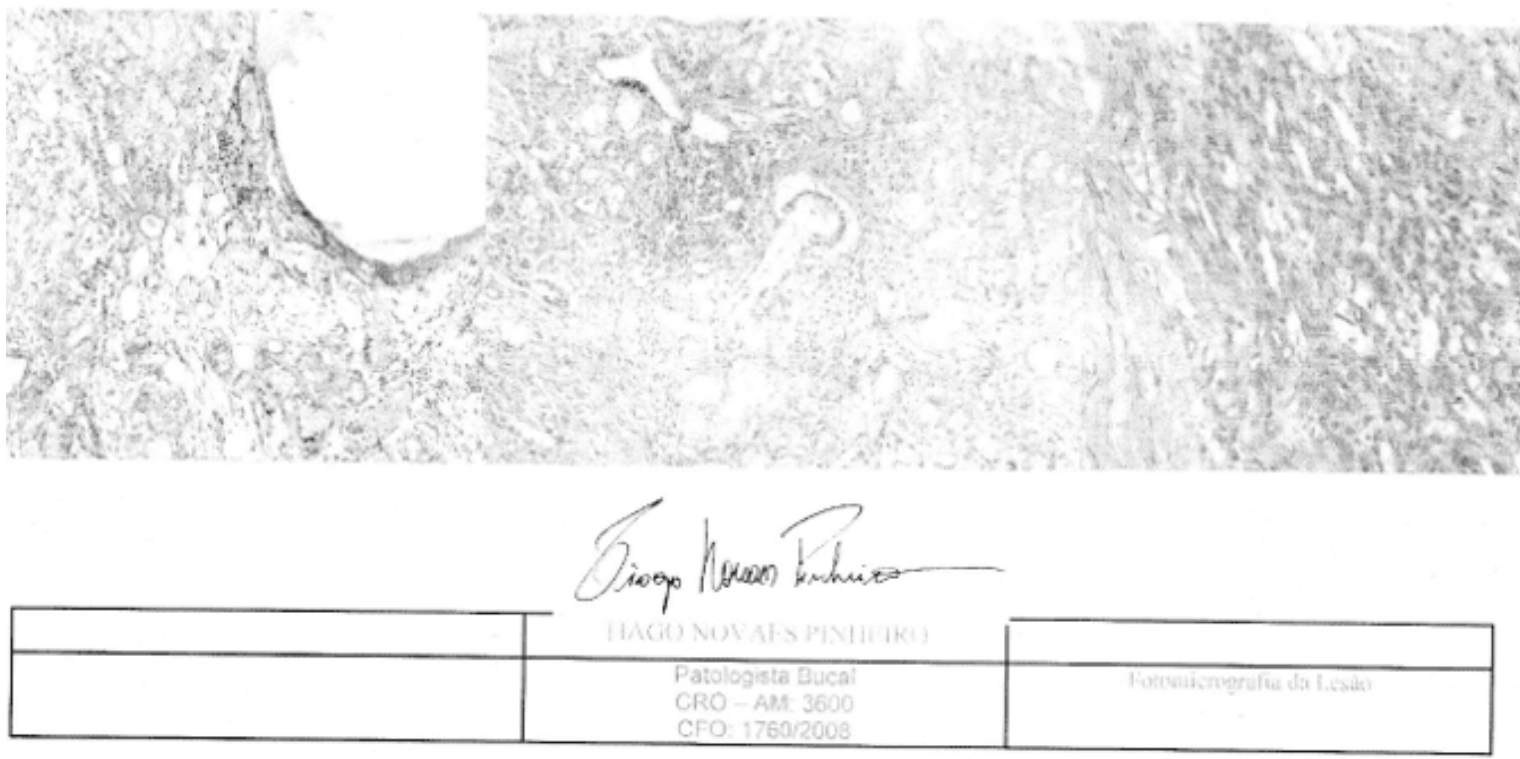



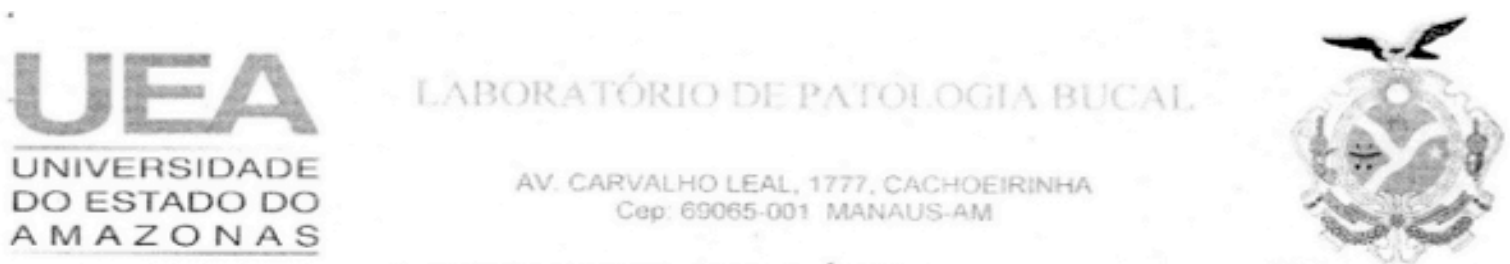

LAUDO HISTOPATOLÓGICO

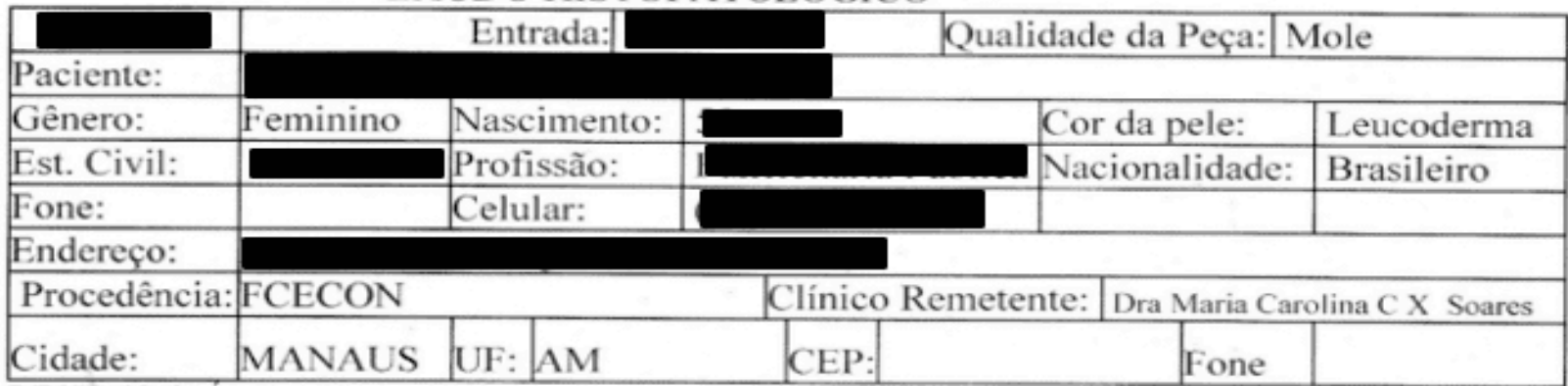

RESUMO CLÍNICO: Frasco 1- Produto de biópsia de palato (Margem Posterior)

Frasco 2- Produto de biópsia de palato (Margem Direita)

Frasco 3- Produto de biópsia de palato (Margem Superior)

HD: Margens comprometidas de carcinoma mucoepidermoide de palato mole.

MACROSCOPIA: Frasco 1- Margem Posterior: (Um frgamento de tecido mole de consistencia mole de forma e superficie irregular, coloração acinzentada, medindo 2,0x1,5x0,8 (4F/2 B)

Frasco 2- Margem Direita: (Seis fragmentos de tecido mole, consistência mole de formsuperficie irregular, coloração acastanhada, medindo em conjunto $5,0 \times 3,5 \times 0,8$ (VF/3B-Tecido duro; 6B-Tecido mole)

Frsaco 3- Margem Superior: (Três fragmnetos de tecido elástico, de consistência elástica, de forma e superficie irregular, colração acastanhada, medindo $21,7 \times 2,0 \times 0,7 \mathrm{~cm}$. (VF/3 B)

MICROSCOPIA: Avaliação de margens de lesão previamente diagnosticada e confirmada por análise imunoistoquimica como CARCINOMA MUCOEPIDERMÓIDE DE GRAU INTERMEDIÁRIO (OMS 2017).

Margem Posterior: Os cortes microscópicos revelam fragmento de mucosa bucal parcialmente revestido por epitélio estratificado pavimentoso paraqueratinizado. Subjacente o tecido conjuntivo é frouxo não modelado, bem colagenizado com glândulas salivares seromucosas apresentando áreas de desorganização da arquitetura acinar, ductos com ectasia e intenso infiltrado inflamatório linfoplasmocitário periacinar e periductal. Nos planos profundos observam-se feixes de fibras musculares estriadas esqueléticas de aspecto habitual. Em uma das regiões periféricas o tecido conjuntivo apresenta alteração basofilica artefatual pela ação térmica do eletrocautério.

\section{MARGENS LIVRES NOS CORTES AVALIADOS}

Margem Direita: Os cortes microscópicos revelam fragmento de mucosa bucal parcialmente revestida por epitélio estratificado pavimentoso paraqueratinizado hiperplásico. Subjacente o tecido conjuntivo é frouxo não modelado. Subjacente o tecido conjuntivo é frouxo não modelado desorganizado por intenso infiltrado inflamatório linfocitário difusamente distribuindo. Destacam-se áreas apresentando ilhotas e ninhos de células intermediárias, mucosas e mioepiteliais plasmocitóides de núcleo pleomórfico e hipercromático, por vezes grande e pálido. Em outros cortes observa-se fragmento de osso trabecular com superfície recoberda por espesso biofilme, apresentando espaços medulares com reabsorção ativa, e invasão de células epiteliais de aspecto acantomatoso e intermediário. além de células claras mucosas e plasmocitóides. Na periferia observa-se mucosa parcialmente revestida por epitélio respiratório de transição com tecido conjuntivo desorganizado por intenso infiltrado inflamatório linfoplasmocitário, além de extensas áreas de necrose coagulativa.

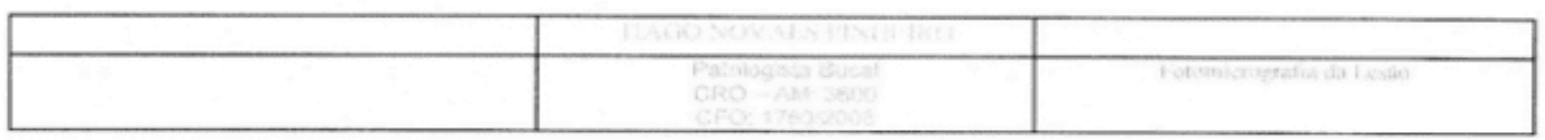




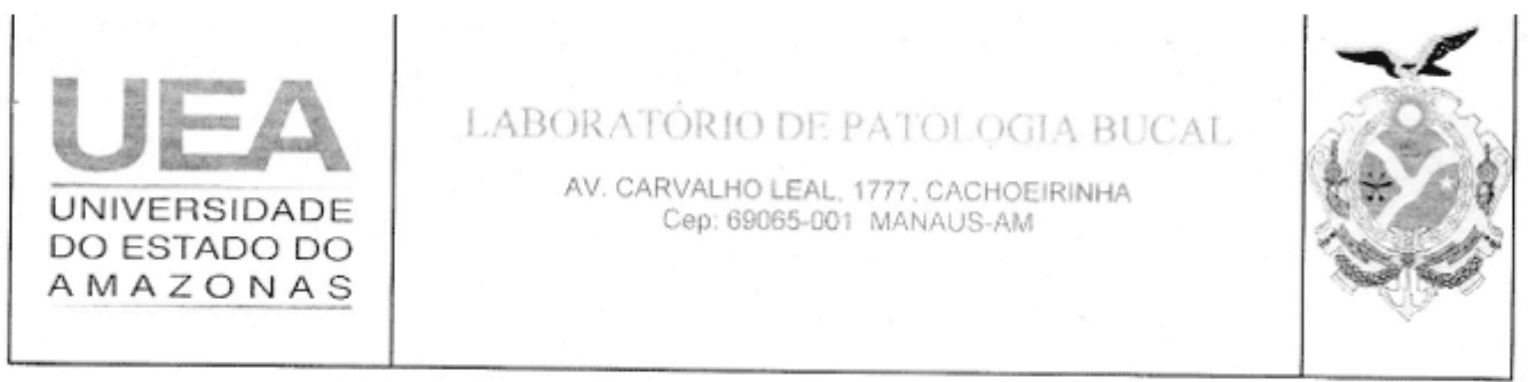

\section{MARGEM COMPROMETIDA (4 DOS 9 BLOCOS AVALIADOS).}

Margem Superior: Os cortes microscópicos revelam fragmento de mucosa nasal revestida por epitélio respiratório transicional com células superficiais colunares ciliadas, apresentando áreas de exocitose leucocitária. Em outras áreas observa-se metaplasia escamosa do revestimento epitelial. Subjacente o tecido conjuntivo é frouxo não modelado desorganizado por intenso infiltrado inflamatório predominantemente linfocitário difusamente distribuido. As glândulas mucosas apresentam arquitetura acinar desorganizada, com ductos ora dilatados ora ectásicos, ora rompidos, com margens periféricas com alteração basofilica por ação térmica. Nos planos profundos observam-se fragmentos de cartilagem hialina de aspecto habitual.

COMENTÁRIO: Devido a marcante presença de artefatos que alteram a estrutura da peça e da intensidade do processo inflamatório presente, não foi possível excluir a possibilidade de comprometimento da margem superior nos cortes dos 3 blocos avaliados.

\section{DIAGNÓSTICO: VER DESCRIČÃO.}

Manaus - AM, 16 de maio de 2018 ;
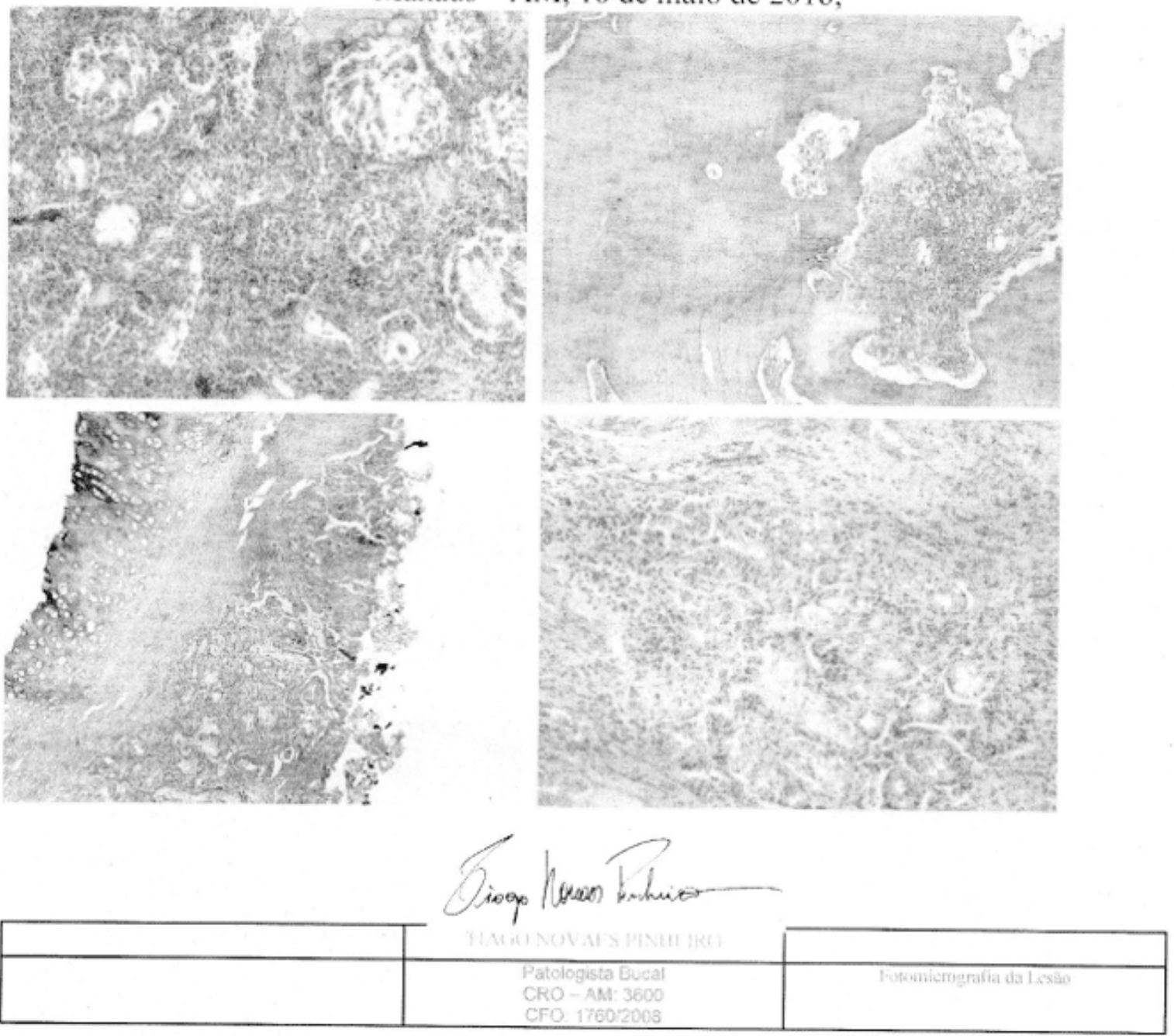

Disponível em: https://www.nucleodoconhecimento.com.br/odontologia/protese-bucomaxilofacial 
Enviado: Abril, 2020.

Aprovado: Julho, 2020. 